Anthropic signatures in alluvium of the Upper Little Tennessee River valley, Southern Blue Ridge Mountains, USA

Lixin Wang* a , David S. Leigh ${ }^{\text {a }}$

${ }^{a}$ Department of Geography, University of Georgia

210 field Street, Athens GA, 30602-2502, USA

*Corresponding author

Email: lixin0@uga.edu

Tel.: +1-706-542-2346

Fax: $+1-706-542-2388$ 


\section{Acknowledgements}

This work was supported by NSF grants DEB-9632854 and DEB-0218001 to the Coweeta LTER. We thank Jacob McDonald and Brad Suther for their assistance in the field and laboratory analyses; Scott Harris for providing laboratory facilities at the College of Charleston

for laser particle size analyses; Dr. George Brook for handling the luminescence dating; and two anonymous reviewers for their valuable comments that help strengthened the manuscript. 


\title{
Anthropic signatures in alluvium of the Upper Little Tennessee River valley, Southern Blue Ridge Mountains, USA
}

\begin{abstract}
Human activities have become important influences on the fluvial system since the postColonial settlement of eastern North America. This research aims to identify post-settlement anthropic signatures in alluvial sediments in the Upper Little Tennessee River valley within the Southern Blue Ridge Mountains, USA, a relatively remote region where agricultural and mining activities were scattered and discontinuous. We compared the physical and chemical characteristics of sediments in post-settlement and pre-settlement stratigraphic units at three separate sites. Chronologies were calculated using non-linear power functions based on radiocarbon, optically stimulated luminescence ages, as well as dates from ${ }^{137} \mathrm{Cs}$ techniques and historic records, which suggest sedimentation rates increased with time during the postsettlement period but decreased with time during the pre-settlement period. In addition, longterm average sedimentation rates are one order-of-magnitude higher in the post-settlement time than in the pre-settlement time. Sediment becomes finer upward through the pre-settlement unit but coarsens-upward in the post-settlement unit. Statistical analyses on adsorbed elemental concentrations suggest that three elements $(\mathrm{Ca}, \mathrm{Hg}, \mathrm{Pb})$ clearly differentiate sediments between pre-settlement and post-settlement periods. The identified anthropic signatures thus include higher sedimentation rates, coarser sediment texture, and higher concentrations of the three elements in the post-settlement units. These probably relate to human activities such as intensive commercial timber harvest and scattered gold mining in the late $19^{\text {th }}$ and early $20^{\text {th }}$ century, modern agricultural practices, and urbanization since the 1970s. Our findings demonstrate significant impact on fluvial systems in regions with very limited history of intense human
\end{abstract}


activities that stand in stark contrast to other parts of the world like Europe and Asia that record thousands of years of anthropic impact.

Keywords: stratigraphy, sedimentology, sedimentation, soil chemistry, geochemistry

\section{Introduction}

Climate change and human activities are the primary drivers of floodplain sedimentation in the late Holocene (Knighton, 1998; Charlton, 2008). Stratigraphic records of floodplain sedimentation provide important information about variations in climate and human impact on the landscape, and geomorphic processes (Gregory et al., 1995; Knighton, 1998; Knox, 1987, 2001, 2006; Macklin, 2003; Lewin, 2005). In many parts of the world such as Europe, Asia, and the Middle East, human activities have a long and continuous history so that anthropic signals appear early within the Holocene (Kalis et al. 2003; Xu et al. 2003; Jones et al. 2013; Leigh et al. 2015). In contrast, in North America, it is generally regarded that the most pronounced and significant human impacts on the fluvial system did not begin until after settlement by nonindigenous people (Trimble, 1974; Jacobson and Coleman, 1986; Knox, 1987; Ambers, 2006; James, 2011). We refer this time period as the post-settlement period. Although some have argued that Native Americans accelerated erosion and sedimentation in eastern North America from agricultural activities during the last 1000 years including the Mississippian and Cherokee cultural periods (Stinchcomb et al., 2011; Dotterweich et al., 2014), such effects may be spatially isolated and not necessarily transmitted to river floodplains. In fact, it has been demonstrated that such pre-settlement impacts are not apparent in the alluvium in the Upper Little Tennessee basin (Leigh, 2016). 
It can be difficult to distinguish the anthropic signals in fluvial sediments from climate signals in regions where significant human activities started thousands of years earlier (Wolf et al. 2014), but in many places in North America, there are clear distinctions between floodplain sediments of the pre-settlement and post-settlement periods that signal human activity. Many studies have found significant differences of overbank sediments between the two periods in terms of sediment textures, sedimentology and sedimentation rates (Lecce, 1997; Knox, 2001, 2006; Benedetti, 2003; Leigh, 2016). Accelerated upland erosion and surface runoff, resulting from intensive human activities such as row-crop agriculture, timber harvest, and land clearing for construction during the post-settlement period (Glenn, 1911; Happ, 1945; Trimble, 1974, Leigh, 2007), has caused coarser sediments and greater sedimentation rates than those of presettlement time (Miller et al., 1993; Knox, 2001, 2006; Benedetti, 2003; Leigh, 2016). In addition to the physical characteristics, chemical characteristics vary significantly as well. For example, the lead and zinc content in overbank sediments increased greatly in the upper Mississippi valley during the 19th century due to mining activities (Knox, 1987; 2006). Mercury $(\mathrm{Hg})$ and gold $(\mathrm{Au})$ concentrations were distinctively higher in post-settlement sediments of Georgia and North Carolina because of past gold mining (Leigh, 1994, 1997; Lecce et al., 2008, 2011; Pavlowsky et al. 2010).

The signs of increased human activity in fluvial sediments are most apparent in regions where post-settlement agricultural and mining activities were long-lasting and pronounced. However, less study has been done in the more remote highlands of the Southern Blue Ridge Mountains, where historic subsistence agriculture was discontinuous and mining activities were low-intensity and scattered. Our research studies sedimentological and geochemical characteristics of overbank sediments in the Upper Little Tennessee River valley, a small 
catchment in these relatively remote highlands. Here we examine the differences between anthropic post-settlement and background pre-settlement periods and identify clear indicators of human impacts on fluvial sediments.

\section{Study Area}

The Upper Little Tennessee River drains a $363 \mathrm{~km}^{2}$ catchment above the United States Geological Survey (USGS) gaging station near Prentiss (USGS gage 03500000), with elevations ranging from 510 to 1600 meters above sea level in northeast Georgia and western North Carolina (Fig. 1). The representative bedrock of the region is quartz dioritic gneiss and biotitic gneiss (Hatcher, 1988; Daniel and Payne, 1990; Robinson et al., 1992), which has been weathered to form a 1-30 m thick mantle of saprolite. The texture of saprolite ranges from sand to clay loam, providing abundant fine sediments to the drainage network (Price and Leigh, 2006; Leigh, 2010). Entisols and Inceptisols are common soil orders on floodplains and the first terraces, which are derived from reworked saprolite, alluvium or colluvial deposits (Leigh, 2010). The Upper Little Tennessee River flows north and is fed predominantly by east- and westflowing tributaries (Fig. 1). The morphology of the channel is characterized by meandering riffles and pools with coarse bed sediments of cobbles to coarse sand, and with finer overbank sediments of fine sand, silt and clay (Price and Leigh, 2006). The region lies in a humid temperate climate zone, with 30-year (1981-2010) average annual precipitation of $1752 \mathrm{~mm}$ and average annual temperature of $13{ }^{\circ} \mathrm{C}$, as recorded at the low elevation climate station of the Coweeta hydrological laboratory.

Humans have been present in the region since the terminal Pleistocene but hunters and gathers of the early and middle Holocene were scattered in low density groups around the 
southeastern U.S. Permanent Native American settlements relying on maize and bean agriculture blossomed around 1000 years ago during the Mississippian cultural period (Delcourt et al. 1986). They were settled mainly on the floodplains with easy access to water and rich alluvial soils for agriculture practice (Swanton, 1946; Gragson and Bolstad, 2007). The indigenous agriculture used simple tools and no mechanized methods and thus was minimally destructive to soil and slope stability (James, 2011). In fact, Leigh (2016) found no increases in floodplain sedimentation rates during the Mississippian and Cherokee agricultural periods based on chronologies from of six well-dated stratigraphic sections. In addition, there is no archaeological or ethnographic evidence to suggest that Native Americans used mineral additives for agriculture nor any metal smelting techniques to generate pollutants (Swanton, 1946; Ethridge and Hudson, 2002). Therefore, with low population density, and limited forest clearance and subsistence crop cultivation, the indigenous people had comparatively little influence on the fluvial sediments in the mountainous environment (Leigh, 2016). Europeans first came to this highland region as traders, missionaries, and military personnel in the $18^{\text {th }}$ century (Gragson and Bolstad, 2007), but the region's population stayed low until the late $19^{\text {th }}$ century, when more European-Americans settled in the region. There was a significant increase in population, agriculture, logging, and mining activities circa. AD 1870 (Leigh, 2010, 2016), as commercial timber harvest moved into the region. A detailed land use history over the past centuries in the region is described by Yarnell (1998) and Harden (2004) with the most notable features being extensive and intensive timber harvest that peaked in the early $20^{\text {th }}$ century, reforestation throughout the region since the 1940s, and vacation home development on hillslopes since the 1970s that has stimulated sustained erosional disturbance. Currently, the land cover classes within the catchment include, 
forest (79.5\%), pasture-grasses-shrubs (11.9\%), developed (7.9\%), cultivated (0.4\%), and others $(0.3 \%)$, according to the latest (2011) land cover data set (Homer et al., 2015).

This research looked at three specific sites in the bottomland of the Upper Little Tennessee River valley, including the Keener $\left(34.9352^{\circ} \mathrm{N}, 83.4220^{\circ} \mathrm{W}\right)$, State Line $\left(34.9980^{\circ} \mathrm{N}\right.$, $\left.83.3807^{\circ} \mathrm{W}\right)$, and Riverside $\left(35.0910^{\circ} \mathrm{N}, 83.3821^{\circ} \mathrm{W}\right)$ sites situated in the upper, middle, and downstream portions of the Little Tennessee River, respectively (Fig. 1). All three sites currently are within pastures and have been the subjects of previous investigations (Price and Leigh, 2006; Leigh, 2007; Leigh, 2010; Wang, 2010; Wang and Leigh, 2012; Leigh, 2016). In this paper, we focus on comparison of post-settlement alluvium against the natural background of the immediate predecessor (previous 2000-3000 years) of late-Holocene pre-settlement alluvium at the three sites.

\section{Methods}

\subsection{Field sampling}

Sediment cores were taken with a trailer-mounted Giddings hydraulic soil probe at each site. Each core was wrapped with plastic and aluminum foil in the field and brought back to the laboratory. In addition to cores, monolith samples were obtained from the exposed vertical cutbanks at the State Line and Riverside sites by pounding PVC troughs into the profile and then meticulously excavating them out. The advantage of monoliths is that they are not compressed and preserve undisturbed layers in the best possible condition. Later in the laboratory, based on stratigraphic correlation and particle size analysis results, data from cores and monoliths were combined into a single profile to take advantage of the intact monolith samples. Samples for optically stimulated luminescence (OSL) dating were taken by pounding gray PVC tubes into 
sand strata and then sealing both ends with black duct tape. Charcoal and uncarbonized plant remains were collected from outcrops and cores for radiocarbon dating, including samples prior to our field work as cataloged by Leigh (2016).

\subsection{Laboratory analyses}

All cores and monoliths were cleaned, photographed and described according to the U.S. Department of Agriculture Soil Survey Manual (Soil Survey Division Staff, 1993). Samples were taken from each core and monolith in 3-14 cm increments to approximate 50 -yr time intervals for pre-settlement sediments and 10-yr time intervals for post-settlement sediments, based on linear age models calculated from previous available dates from Price and Leigh (2006) and Leigh (2007). Abrupt and clear stratigraphic boundaries were more closely bracketed by smaller sampling intervals. Samples were oven dried at $55^{\circ} \mathrm{C}$ and then sieved through $2 \mathrm{~mm}$ mesh. Particles larger than $2 \mathrm{~mm}$ were weighed and discarded, while particles smaller than 2 $\mathrm{mm}$ were retained for further analysis.

Approximately $0.5 \mathrm{~g}$ samples were taken for particle size measurements with an automatic laser particle size analyzer (CILAS 1180) in the Department of Geology and Environmental Geosciences at the College of Charleston. Samples were pretreated with 30\% hydrogen peroxide $\left(\mathrm{H}_{2} \mathrm{O}_{2}\right)$ to remove humus and then soaked in a sodium metaphosphate solution $(50 \mathrm{~g} / \mathrm{L})$ to disperse clay aggregates before being introduced into CILAS 1180 . The machine measures particles from $0.04 \mu \mathrm{m}$ to $2500 \mu \mathrm{m}$ and produces a continuous distribution of particle sizes. Traditional wet sieve and pipette methods were run on selected samples and the results were compared with the laser results, which showed a substantial underestimation of clay content by CILAS (Wang, 2010). This difference results from the non-sphericity of the particles, and is particularly significant for clay particles because of their platy form. Konert and 
Vandenberghe (1997) suggested a particle size of $8 \mu \mathrm{m}$ by laser particle sizer is equivalent to $<2$ $\mu \mathrm{m}$ particle sizes by pipette method. According to this, when describing particle size data from CILAS using the program GRADISTAT 4.0 (Blott and Pye, 2000), we treated the particles defined as fine and very fine silt in GRADISTAT 4.0 as clay and actually used $8 \mu \mathrm{m}$ as the boundary between silt and clay.

Samples of approximately $5 \mathrm{~g}$ were oven dried at $110^{\circ} \mathrm{C}$ and then burned in a muffle furnace at $550^{\circ} \mathrm{C}$ for four hours for loss on ignition (LOI) estimation. Weight loss from this process primarily comes from the combustion of organic matter (Dean, 1974; Heiri et al., 2001) but also includes dewatering of clay minerals and oxides (Beaudoin, 2003; Santisteban et al., 2004, Hoogsteen et al., 2015). Therefore, LOI values reflect variations imparted by organic matter, percent clay, and oxyhydroxides.

For chemical analysis, aqua regia (hot nitric:hydrochloric acid,1:3 ) was used to dissolve readily soluble matter and to remove extractable elements from the exterior of sediment grains that had been passed through a stainless steel mesh at $0.25 \mathrm{~mm}$. Concentrations of 34 extractable elements were measured by inductively coupled plasma-atomic emission spectroscopy, and mercury $(\mathrm{Hg})$ was analyzed by cold vapor atomic absorption spectrometry. The chemical analyses were conducted by a private commercial laboratory (ALS Chemex) with analytical precision certified to be within $10 \%$ of the detection limits.

Chronology of the three sediment profiles was based on ages obtained using four different techniques: OSL, radiocarbon, ${ }^{137} \mathrm{Cs}$, and historic records. Three OSL samples were dated in the University of Georgia Luminescence Dating Laboratory. Samples were pretreated according to Srivastava et al (2005) and paleodose was determined using single-aliquot 
regenerative-dose protocol (Murray and Wintle, 2000). Ages were calculated using the ANALYST program of Duller (1999).

Radiocarbon $\left({ }^{14} \mathrm{C}\right)$ samples were dated at the University of Georgia Center for Applied Isotope Studies using a National Electrostatics Corporation Model 1.5SDH-1500 kV Accelerator Mass Spectrometer. Calendar year calibrations were calculated using the program CLAM (Blaauw 2010) based on the IntCal-13 calibration curve (Reimer et al. 2013) and the delta ${ }^{13} \mathrm{C}$ corrected ${ }^{14} \mathrm{C}$ ages. The estimates of calendar years before present (years BP) reference AD 1950 as present, and the single age assigned to each sample is the "best estimate" of the CLAM program according to the calibrated probability distributions and linear age-depth modeling as summarized by Leigh (2016). To be consistent with OSL ages, all calibrated radiocarbon dates were converted to years before AD 2009.

The radioactive isotope ${ }^{137} \mathrm{Cs}$ content of sediments was measured by gamma spectrometry with a high purity germanium crystal system coupled with an Ortec digital spectrometer in the University of Georgia Geomorphology Laboratory, with count times of 5000 to 10000 seconds to achieve analytical errors $<10 \%$. Samples at $2 \mathrm{~cm}$ intervals were measured to obtain a tightly constrained estimate of AD 1963 with ${ }^{137} \mathrm{Cs}$. We adhere to the idea that maximum content of ${ }^{137} \mathrm{Cs}$ in the stratigraphic section represents the year AD 1963 (Ritchie and McHenry, 1990; Walling and He, 1997). However, at the Keener site the maximum ${ }^{137} \mathrm{Cs}$ content was blurred within the bioturbated and possibly plowed A horizon, so as an alternative we used the first distinct increase and peak in ${ }^{137}$ Cs as AD 1958 (Ritchie and McHenry, 1990; Walling and He, 1997). Ages of certain sand layers in the post-settlement unit were estimated by correlating the sedimentological evidence of very large floods with USGS gaged flood records (i.e. the two largest floods on record in1902 and 1964) as explained by Leigh (2016). 


\subsection{Statistical analyses}

Chemical elements adsorbed to the surface of sediments are strongly influenced by particle sizes and organic matter content. The negative charge possessed by organic colloids and relatively large surface area of finer particles make them adsorb more cations (Horowitz, 1991). Since our LOI values integrate clay, organic carbon, and oxyhydroxides (Hoogsteen et al. 2015) that adsorb cations, we normalized the original elemental concentrations by running linear regressions against LOI values, and used the residual values in the subsequent statistical analyses. Because Native Americans in the region did not exploit metals as in other parts of the world where metal smelting started thousands of years ago (Swanton, 1946; Ethridge and Hudson, 2002; Killick and Miller, 2014; Liu et al. 2015), we believe the geochemical data in the presettlement unit should reflect the natural variations under non-anthropic conditions. Therefore, linear regression of the elemental concentrations against LOI were generated using data from unit $1 \mathrm{VAb}$ and then the equations were used to generate residual values for both unit $1 \mathrm{VAb}$ and 2VA, separately for each site. In cases where LOI is not a significant predictor ( $p$-values $\geq 0.05$ ), the residuals were simply calculated by subtracting the mean of the $1 \mathrm{VAb}$ values. Such normalization is rather common in studies of trace metals on fluvial sediment (Miller and Miller, 2007; Pavlowsky et al., 2010; Leece et al., 2011), and the analysis of residual values is a very standard approach in regression analysis (Draper and Smith, 1998).

After checking the data normality, a t-test or U-test was run on the descriptive statistics of particle sizes and chemical residuals to assess the differences of physical and chemical characteristics between the pre-settlement and post-settlement vertical accretion deposits. The most differentiating elements then were used as predictors in discriminant function analysis (DFA) to test their ability of predicting post-settlement or pre-settlement groups. Statistical 
analyses of t-test, U-test and DFA were run in the program language R (R Development Core Team, 2008).

\section{Results}

\subsection{Stratigraphy}

Buried $\mathrm{A}(\mathrm{Ab})$ horizons are prevalent in the stratigraphy of older floodplains or terraces in many places, containing more organic matter and appearing darker than the overlying postsettlement alluvium. The Ab horizons likely represent the land surface that existed prior to the time of initial European-American settlement (Happ, 1945; Trimble, 1974; Costa, 1975; Jacobson and Coleman, 1986; Knox, 1987, 2001, 2006; Leigh, 2010; Leigh, 2016). Age of the $\mathrm{Ab}$ horizon varies among studies depending on the specific settlement and land use history of a region. We used the upper boundary of the $\mathrm{Ab}$ horizon to divide the sedimentary profile into two major stratigraphic units (Fig. 2): the pre-settlement unit (unit 1) below the boundary and the post-settlement unit (unit 2) above the boundary. This boundary line was assigned a date of AD 1870, as determined by Leigh $(2010,2016)$.

The thickness, sediment color, and texture of each stratigraphic unit vary across the three sites. Visually, the Keener site has darker and finer sediments and a much thinner unit 2 than those of the State Line and the Riverside sites. However, all three sites show similar stratigraphic assemblages of facies. The pre-settlement unit 1 can be divided into three zones based on sediment structures and textures. The bottom zone contains sub-rounded to wellrounded gravels and coarse sand. The middle zone is composed primarily of medium and coarse sand with massive to weak blocky structure and redox features, and it commonly exhibits thin bedding of sand and uncarbonized organic material. The upper zone is characterized by a sandy fining-upward sequence in the initial lower portion that conformably grades upward into silty 
clay loam with pedogenic features (i.e. moderate fine to medium blocky structures). Although generally fine textured, several thin beds and laminae of fine sand are apparent in the upper zone, especially at the State Line and Riverside sites. Referring to the sediment texture and stratigraphic characters of typical floodplain deposits of meandering streams (Nichols, 1999; Boggs, 2006, Bridge, 2003), we designated the bottom zone as unit 1B, representing bedload deposits that were transported and deposited in a previous channel; the middle zone unit 1LA (lateral accretion), representing point bar deposits from lateral migration of the meandering channel; and the upper zone unit 1VA (vertical accretion), representing deposits that fell out of suspension during overbank floods. At the Keener and Riverside sites, unit 1VA was subdivided into 1VAa and 1VAb to separate the distinct fining-upward sequence of the lower part (1VAa) from the more homogenous upper part (1VAb). The post-settlement unit 2 is primarily composed of fine sand and silt loam, with several distinct light-colored medium and coarse sand layers. Overall, a coarsening-upward trend is shown in the upper part of unit 2 at all three sites (Fig. 2, sand\% and D90). Pedogenic features of granular and blocky structures are present at the Keener site but not at the State Line and the Riverside sites, where sediments are massive with thin laminations. Roots and other evidence of bioturbation are common. Sediments in this unit are from overbank deposition after European-American settlement and thus the upper unit was designated as unit 2VA.

For this research, our focus is on the vertical accretion units 1VA and 2VA, as they represent comparable sedimentary environments. At the Keener and Riverside sites, only unit $1 \mathrm{VAb}$ was quantitatively compared with unit 2VA in terms of particle size and geochemistry, because 2VA does not have a distinct lower part with fining-upward sandy sediment like 1VAa.

\subsection{Chronology and age vs. depth models}


The age estimates from samples at the Keener, State Line, and Riverside sites are shown in Table 1. All the ages are within the last 2700 years and the Keener and State Line are younger than 1600 years. Ages of 1LA/1VA boundaries were assigned the same age as the underlying lateral accretion deposits, because lateral accretion typically occurs almost instantaneously during individual floods before being overlain by steady incremental additions of vertical accretion deposits. The surface of $\mathrm{Ab}$ horizon as $1 \mathrm{VA} / 2 \mathrm{VA}$ boundary was assigned an age of AD 1870, when population, agriculture, logging and mining activities in the study area started to increase significantly (Leigh, 2010; 2016). Samples in the upper part of unit 2VA with a pronounced increase of $>0.25 \mathrm{~mm}$ fraction and immediately above the AD 1963 peak of ${ }^{137} \mathrm{Cs}$ content were assigned an age of AD 1964 corresponding to the largest flood on record at the nearby Prentiss gage. At the State Line site, another sample with a pronounced increase of $>0.25$ mm fraction in lower 2VA was keyed to the AD 1902 large flood according to the deactivated gage downstream at Needmore. This AD 1902 age assignment was also established in another core at the same site, which contains railroad grade materials suggesting an age a few years earlier than the railway reached the State Line site in AD 1905 (Leigh, 2016). The surface of each site was assumed to be an age of AD 2009, the time when the cores were drilled.

In order to characterize overbank vertical accretion, Wolman and Leopold (1957) promoted a model (assuming natural conditions) wherein overbank sedimentation rates decrease with time as the floodplain surface accreted. Bridge (2003) expanded upon this by arguing that the deposition of overbank finning-upward sequence can be expressed by a general power function of $R=10 t^{-0.33}$ ( $R$ : sedimentation rate, in $\mathrm{cm} / \mathrm{yr}$; $t$ : age of deposition, in year). If transferring to an age vs. depth $(\mathrm{d}=\mathrm{f}(\mathrm{t})$, d: thickness of accumulation, in $\mathrm{cm}$; t: age of accumulation, in year) relationship, it would result in a power function with an exponent of 0.67 . 
We applied this concept to unit 1VA and adjusted the constant and exponents for our data at the three sites, and all three age vs. depth power functions have exponents smaller than 1 , and fitted 1VA ages very well $\left(r^{2} \geq 0.97\right)$ (Fig. 3). However, in stark contrast, Wolman and Leopold's and Bridge's conceptual models of decreasing accretion rates with time do not apply for the postsettlement period. Instead, we found that age vs. depth power functions with exponents larger than 1 best fit the 2VA ages $\left(\mathrm{r}^{2}=1\right)$, indicating increasing rates with time (Fig. 3 ).

\subsection{Sedimentation rates and particle size}

The sedimentation rates $R$ (in $\mathrm{cm} / \mathrm{yr}$ ) derived from the age-depth models are shown in Table 2. All the age vs. rate power functions have negative exponents for the pre-settlement period and positive exponents for the post-settlement period, suggesting decreasing rates over time in the pre-settlement period and increasing rates over time in the post-settlement period. Table 2 also shows the long-term average sedimentation rates at different time intervals. The State Line site had the highest rates for both post-settlement $(11.78 \mathrm{~mm} / \mathrm{yr})$ and pre-settlement $(1.07 \mathrm{~mm} / \mathrm{yr})$ periods; the lowest post-settlement rate was at the Keener site $(3.18 \mathrm{~mm} / \mathrm{yr})$; and the lowest pre-settlement rate was at the Riverside site $(0.46 \mathrm{~mm} / \mathrm{yr})$. However, at all three sites, long-term average sedimentation rates during post-settlement time (AD 1870 - 2009) were about one order-of-magnitude greater than pre-settlement (before AD 1870) rates. Within the postsettlement period, rates after AD 1964 were nearly twice as high as those before AD 1964 (Table 2).

In contrast to the remarkably different sedimentation rates between post-settlement and pre-settlement periods, the t-test on particle size characteristics, including mean, D90, percentage of sand fractions larger than $0.25 \mu \mathrm{m}$, percentage of sand, sorting, kurtosis, and skewness, 
between 1VA and 2VA did not show significant differences at the $95 \%$ confidence level, except at the Riverside site (Table 3). However, as shown on Fig. 2, at all three sites, sediments exhibit a fining-upward trend in unit 1VAb but a coarsening-upward trend in 2VA.

\subsection{Geochemistry}

Of the analyzed 35 chemical elements, 15 of them do not have discrete concentration values (censored values below detection limits), so they were excluded from statistical analyses. For the remaining 20 elements, original concentrations (in ppm or \%) were plotted against depth at each site (Fig. 4).

In most cases, LOI appears as a significant predictor (p-values $<0.05$ ) of the elemental concentrations except for several elements (Table 4). The residuals, either from the linear regression (r) or relative to the background mean (m), were plotted against depth at each site to see the downcore trend (Fig. 5). We used the $90^{\text {th }}$ percentile of $1 \mathrm{VAb}$ residuals to represent the "uppermost" background level, and shaded the area when residuals in 2VA are above this level. It is clear that the majority of elements in 2VA are considerably below the background level, and that some elements exhibit distinct shifts at the 1VA/2VA boundary but the direction of shifts was not consistent at all three sites (such as $\mathrm{K}, \mathrm{Mn}, \mathrm{P}, \mathrm{Ti}$ ), so they could not be logically related to anthropic drivers. Only $\mathrm{Ca}, \mathrm{Hg}$, and $\mathrm{Pb}$ have greater values at all three sites for multiple samples in 2VA when compared to the uppermost background level in 1VAb. The t-test or Utest of the residuals between unit 1VAb and 2VA indicate no single element has significantly $(\mathrm{p}<0.05)$ higher values in $2 \mathrm{VA}$ than in $1 \mathrm{VAb}$ at all three sites (Table 5). In fact, $\mathrm{Ca}, \mathrm{Hg}$, and $\mathrm{Pb}$ are the only three elements that have significantly higher values in 2VA than 1VAb at two of the three sites (Table 5). Therefore, based on the downcore trend and t-test/U-test, elements $\mathrm{Ca}, \mathrm{Hg}$, 
and $\mathrm{Pb}$ were chosen as the best candidates for "signature elements" because the normalized data show consistently higher values in $2 \mathrm{VA}$ than in $1 \mathrm{VAb}$ at all three sites, and the differences are significant $(\mathrm{p}<0.05)$ at least at two of the three sites.

Discriminant function analysis on the three elements' residuals, percentages of sand, and LOI values shows that the five predictors performed well in predicting whether a sample belongs to the pre-settlement and post-settlement groups, with predictive accuracy greater than $89 \%$ (Table 6). The standard coefficient from the DFA also shows strong ability of these elements in differentiating the two units, particularly $\mathrm{Hg}$ and $\mathrm{Ca}$ (Table 6).

\section{Discussion}

\subsection{Sedimentation and human activities}

The negative exponents of sedimentation rate functions during the pre-settlement period indicate decreasing rates with time, while the positive exponents during the post-settlement period suggest increasing rates with time. Based on prevailing knowledge about natural process of floodplain development (Wolman and Leopold, 1957; Bridge, 2003), a decreasing rate with time should be expected. Thus, the increasing rates with time during post-settlement time are abnormal to the widely accepted process of vertical accretion sedimentation and might have been driven by human-induced changes in the system.

Our pre-settlement strata are confined to the last 2700 years, which includes early agricultural development by Native Americans. However, as mentioned earlier, their land use practices were limited to forest management (nut harvest and hunting) and subsistence crop cultivation that were patchy and dynamic (Munoz et al., 2014) with little influence on erosion and floodplain sedimentation in our study area (Van Doren, 1928; Swanton, 1946; Delcourt et al. 
1986; Leigh, 2016). Impact on the landscape became significant and widespread only after the European-American settlement or during post-settlement time. Clear-cutting for timber harvest was intensive, and widespread row-crop agriculture also occurred in the late 19th and early 20th century (Yarnell, 1998; Harden, 2004), causing soil erosion on upland slopes and accelerated sedimentation in lower valleys, as noted by Glenn (1911). The federal acquisition of Appalachian land in 1911 and later established national forests and regulated logging activities (Yarnell, 1998; Harden, 2004), but human disturbance on private land persisted in the form of forest clearing, agriculture, urbanization, and road construction (Price and Leigh, 2006; Kirk et al., 2012). Especially since the 1970s, as more people migrated to this area, second-homes and roads have been built on sloping portions of the basin (Leigh, 2007; 2010; Kirk et al., 2012). Meanwhile, agricultural practices in lower valleys currently emphasize livestock over growing row crops (Harden, 2004). These human activities led to accelerated soil erosion and hillslope failures, which provided substantial amounts of sediments to floodplains (Leigh and Webb, 2006; Knox, 2006; Leigh, 2016), leading to the significant increases of our observed post-settlement sedimentation rates.

The coarsening-upward trend of in the upper part of unit 2VA could be affected by three factors. First, channel lateral migration and levee progradation can produce coarsening-upward overbank sediments. That is, sediments closer to the channel are generally coarser (Lecce, 1997; He and Walling, 1998), and with the lateral shift of the channel the cutbank is eroded and newer sediments on top of the cutbank are generally coarser than the underlying sediments because the deposition site is inherently closer to the channel. Second, source sediments could have become coarser. Sediments in the drainage basin came primarily from slope erosion in the upland soil (Glenn, 1911). During early post-settlement time, soil erosion first occurred in the relatively fine 
solum, but later, gully erosion cut deep into the underlying sandy saprolite (Glenn, 1911; Leigh and Webb, 2006), providing coarser sediments to the river channel. Third, land use changes can introduce coarser sediment to the channels via changes in hydrology that favor more energetic floods. Population growth and low density urban development in the region became rapid since the 1960s (Kirk et al., 2012). Land cover changes from forest to pasture and toward more urbanized land (including more roads and driveways) increased surface runoff and produced larger flood discharges that are able to transport and deposit coarser sediments during overbank floods (Sutherland et al., 2002; Chin, 2006). All three factors may have caused the coarseningupward trend in the late post-settlement vertical accretions. However, given that little lateral migration of the main stem of the Upper Little Tennessee River has occurred over the past century (Leigh, 2010), we argue that the first reason is less important. The other two reasons are more influential and both are related to increased human activities in the region.

\subsection{Signature elements and human activities}

Three chemical elements $(\mathrm{Ca}, \mathrm{Hg}, \mathrm{Pb})$ were determined as anthropic signatures based on higher residual (or ratio to background mean) values in 2VA than the background level in 1VAb, and statistical test results with significant difference between the stratigraphic units at two of the three sites. Logically, the three elements are clearly related to human activities as $\mathrm{Hg}$ and $\mathrm{Pb}$ are obvious environmental contaminants and $\mathrm{Ca}$ is commonly used as an agricultural additive.

A gold-belt trends across the southeastern United States (Pardee and Park, 1948), including the Upper Little Tennessee watershed, and gold mining was quite active during the late 1800s and early 1900s (Lecce et al. 2011). Mercury (Hg) was used extensively in early gold mining to amalgamate and recover gold from sluices and stamp mills (Pardee and Park, 1948). 
This activity has significantly impacted the fluvial systems in that mercury was transported with sediments, reworked by fluvial process, and stored in overbank sediments (Leigh, 1994, 1997; Lecce et al., 2008). There were no major gold mining operations near the three study sites, but scattered prospecting occurred in the Upper Little Tennessee catchment during the early 1900s (Robinson et al., 1992). This probably is the primary reason for the significantly higher amounts of $\mathrm{Hg}$ in the post-settlement vertical accretions. Although gold mining stopped in the 1940s (Robinson et al., 1992), channel migration could have reworked the sediments and redistributed mercury in the watershed (e.g. Leigh, 1997). In addition, atmospheric fallout clearly is another possible source of mercury to the soils (Nriagu, 1994).

Lead $(\mathrm{Pb})$ was a minor associate of the gold ore in the gold-belt, and lead mining was also active during the early post-settlement time (Eller, 1982; Robinson et al., 1992). Actually, the raw concentrations and residuals of the two elements are strongly correlated at all three sites. Therefore, the increase of $\mathrm{Pb}$ in post-settlement sediments may also be related to mining activities and atmospheric fallout. In addition, we think past use of leaded fuel is another source of $\mathrm{Pb}$ to the late post-settlement sediments. Lead was blended with gasoline between the early 1920s and 1990s and automobile exhaust has been an important source of lead pollution to the environment. Even though the United States Environmental Protection Agency began regulating lead content in gasoline in 1973, leaded fuel was still available until the Clean Air Act became effective in 1996. Even if the use of leaded gasoline has decreased since the 1970s, reworking of sediments and the redistribution of lead in the watershed may have maintained $\mathrm{Pb}$ at higher levels in the overbank sediments.

As a geochemically mobile element in soil solutions, Ca could be leached downward in the profile after deposition. The low residual values in unit $1 \mathrm{VAb}$ might be a result of intense 
leaching during pedogenesis, whereas the younger sediments in 2VA did not experience much leaching and would be expected to have higher values. At all three sites, the lower parts of unit 2VA also have notably depleted Ca residuals, suggesting leaching was possible in the 2VA unit. Therefore, the much higher values of Ca residuals toward the top of unit 2VA should be related to lime use as an agricultural supplement. Soils in the Southern Blue Ridge Mountains are generally acidic and application of lime is a common practice to reduce acidity in agricultural fields (Messick et al., 2001). However, the application of lime did not occur in the region until the 1930s and later, according to local agricultural records (Yarnell, 1998; Messick et al., 2001).

Although we argued in the previous section that sediment sources may have become coarser as upland erosion progressed down into the underlying sandy saprolite during late postsettlement time, this does not affect the geochemical results because we examined values normalized for particle size variation of the adsorbed chemical elements, rather than the wholesoil geochemistry. Indeed adsorbed elemental concentrations are greatly influenced by particle size via available surface area with finer sediments having higher concentrations (Horowitz, 1991; Miller and Miller, 2007; Pavlowski et al., 2010; Lecce et al., 2011), but our linear regression and analysis of residual values intentionally masks the variation driven by particle size. Also, since we are focusing on adsorbed elements, rather than total chemical composition of the sediment samples, any primary mineral and chemical differences within the coarse sediment grains derived from soil versus saprolite are not included.

\subsection{Justification of "anthropic signatures"}

In spite of the geomorphic and sedimentologic variability among the three sites, physical and chemical characteristics of floodplain overbank sediments showed significant differences 
between post-settlement and pre-settlement periods. Therefore, in certain cases where identifying the Ab horizon is difficult due to coring disturbance or flood scouring (Happ, 1945), the sedimentation rates, sediment textures, and signature elements could be used to help differentiate post-settlement and pre-settlement sediments. The high predictive accuracy of these factors in DFA (Table 6) proved that they are quite effective in differentiating the two units.

These physical and chemical characteristics are designated here as "anthropic signatures" to reflect their connections with human activities. We are aware that sedimentation rates and sediment textures were not caused solely by human activities. The autogenic process of floodplain development, such as natural levee progradation associated with channel lateral migration, was at least partly responsible for the increased sedimentation rates and the coarsening-upward trend in the upper post-settlement sediments. In addition, the frequency of high-magnitude floods increased in the past several decades according to the USGS Prentiss gage on the Little Tennessee River, and more frequent large floods could contribute to the increased sedimentation rates as well (Knox, 2006; Leigh and Webb, 2006). Although multiple factors acted on the fluvial system, given the close correlation between these substantial changes and human activities, we believe that direct human impacts overshadowed other factors during post-settlement time. Therefore, these "anthropic signatures" appear to be good indicators of human influence.

\section{Conclusion}

We compared the physical and chemical characteristics of floodplain vertical accretion deposits at three sites in the Upper Little Tennessee River valley of the Southern Blue Ridge Mountains, USA, a region where significant human impact on the landscape did not begin until 
after intensive and extensive settlement of European-Americans in the late $19^{\text {th }}$ century. The comparison showed great differences between post-settlement (after AD 1870) and presettlement (Before AD 1870) periods. Post-settlement sedimentation rates increased with time while pre-settlement rates decreased with time, and the long-term average sedimentation rates during post-settlement time were about one order-of-magnitude greater than that during presettlement time. Sediments in pre-settlement vertical accretion deposits exhibit a fining-upward trend, but a coarsening-upward trend is apparent in post-settlement vertical accretion. The three "signature elements" $(\mathrm{Ca}, \mathrm{Hg}, \mathrm{Pb})$ have significantly higher content in post-settlement sediments than in pre-settlement sediments. These substantial changes between the two periods are most likely related to human impacts, such as timber harvest and gold mining during early postsettlement time, lime use for agricultural practice, land clearing for urbanization after the 1970s, and even atmospheric influx of $\mathrm{Hg}$ and $\mathrm{Pb}$. Even though the autogenic process of floodplain development and climate changes in the recent decades also accounted partly for these changes, we argue that such significant changes are more related to human activities. Thus the sedimentation rates, sediment texture and three elements $(\mathrm{Ca}, \mathrm{Hg}, \mathrm{Pb})$ were identified as "anthropic signatures". This research demonstrates significant human impact on fluvial systems even in regions with only a centennial history of intense human activities as compared to other parts of the world where human impacts are apparent for millennia.

\section{References}

Ambers, R.K.R., Druckenbrod, D.L., Ambers, C.P., 2006. Geomorphic response to historical agriculture at Monument Hill in the Blue Ridge Foothills of Central Virginia. Catena 65, 49-60.

Beaudoin, A. 2003. A comparison of two methods for estimating the organic matter content of sediments. Journal of Paleolimnology 29, 387-390. 
Benedetti, M.M., 2003. Controls on overbank deposition in the Upper Mississippi River. Geomorphology 56, 271-290.

Blaauw, M., 2010. Methods and code for 'classical' age-modelling of radiocarbon sequences. Quaternary Geochronol 5, 512

Blott, S., Pye, K., 2001. GRADISTAT: A grain size distribution and statistics package for the analysis of unconsolidated sediments. Earth Surface Processes and Landforms 26, 1237-1248.

Boggs, S., 2006. Principles of sedimentology and stratigraphy, 4th ed. Pearson Prentice Hall, Upper Saddle River, N.J., pp 662

Bridge, J.S., 2003. Rivers and Floodplains: Forms, Processes, and Sedimentary Record. Blackwell Science Ltd, Xoford, UK.

Costa, J.E., 1975. Effects of agriculture on erosion and sedimentation in Piedmont province, Maryland. Bulletin of Geological Society of America 86, 1281-1286.

Charlton, R., 2008. Fundamentals of Fluvial Geomorphology. Routledge, London and New York, pp. 234.

Chin, A., 2006. Urban transformation of river landscapes in a global context. Geomorphology 79, 460487.

Daniel, C.C., Payne, R.A., 1990. Hydrogeologic unit map of the Piedmont and Blue Ridge provinces of North Carolina. Water Resources Investigations Report, vol. 90-4035. U.S. Geological Survey, Raleigh, NC.

Dean, W.E., 1974. Determination of carbonate and organic matter in calcareous sediments and sedimentary rocks by loss on ignition: Comparison with other methods. Journal of Sedimentary Petrology 44, 242-248.

Delcourt, P.A, Delcourt, H.R, Cridlebaugh, P.A, and Chapman, J., 1986. Holocene ethnobotanical and paleoecological record of human impact on vegetation in the Little Tennessee River Valley, Tennessee. Quaternary Research 25, 330-349.

Dotterweich, M., Ivester, A.H., Hanson, P.R., Larsen, D., Dye, D.H., 2015. Natural and human induced prehistoric and historical soil erosion and landscape development in southwestern Tennessee, USA. Anthropocene 8 (1), 6-24.

Draper, N.R, Smith, H., 1998. Applied Regression Analysis, Third Edition. Wiley, New York.

Duller, G.A.T., 1999. Luminescence Analyst computer programme v2.18. Department of Geography and Environmental Science. University of Wales, Aberystwyth.

Eller, R.D., 1982. Miners, Millhands, and Mountaineers: Industrialization of the Appalachian South 1880-1930. Knoxville, TN: University of Tennessee Press.

Ethridge, R., Hudson, C., 2002. The Transformation of the Southeastern Indians, 1540-1760. Jackson: University Press of Mississippi.

Glenn, 1911. Denudation and erosion in the southern Appalachian region and the Monongahela Basin. USGS Professional Paper 72, 137 
Gragson, T.L., Bolstad, P.V., 2007. A local analysis of Early-eighteenth-century Cherokee Settlement. Social Science History 31(3), 435-468.

Gregory, K.J., Starkel, L., Baker, V.R., 1995. Global Continental Palaeohydrology. Wiley, Chichester.

Happ, S.C., 1945. Sedimentation in South Carolina Piedmont Valleys. American Journal of Science 243(3), 113-126.

Harden, C.P., 2004. Fluvial response to land-use change in the southern Appalachian region: a century of investigation. Physical Geography 25, 398-417.

Hatcher, R.D., 1988. Bedrock geology and regional geologic setting of Coweeta Hydrologic Laboratory in the eastern Blue Ridge. In: Swank, W.T., Crossley, D.A. (Eds.), Forest Hydrology and Ecology at Coweeta. Springer-Verlag, New York, pp. 81-92.

He, Q., Walling, D.E., 1998. An investigation of the spatial variability of the grain size composition of floodplain sediments. Hydrological Processes 12, 1079- 1094.

Heiri, O., Lotter, A.F., Lemcke, G., 2001. Loss on ignition as a method for estimating organic and carbonate content in sediments: Reproducibility and comparability of results. Journal of Paleolimnology 25, 101-110.

Hoogsteen. M . J . J,, Lantingaa, E.A., Bakker, E.J., Groot, J.C.J., Tittonell, P.A., 2015. Estimating soil organic carbon through loss on ignition: effects of ignition conditions and structural water loss. European Journal of Soil Science 66, 320-328.

Homer, C.G., Dewitz, J.A., Yang, L., Jin, S., Danielson, P., Xian, G., Coulston, J., Herold, N.D., Wickham, J.D., and Megown, K., 2015. Completion of the 2011 National Land Cover Database for the conterminous United States-Representing a decade of land cover change information. Photogrammetric Engineering and Remote Sensing 81, 345-354.

Horowitz, A.J., 1991. A Primer on Sediment-trace Element Chemistry. Lewis, MI, USA, pp.134.

James L.A., 2011. Contrasting geomorphic impacts of pre- and post-Columbian land-use changes in Anglo America. Physical Geography 32, 399-422.

Jacobson, R.B., Coleman, D.J., 1986. Stratigraphy and recent evolution of Maryland Piedmont floodplains. American Journal of Science 286, 617-637.

Jones, S. E., C. O. Hunt, H. Barton, C. J. Lentfer and P. J. Reimer, 2013. Forest disturbance, arboriculture and the adoption of rice in the Kelabit Highlands of Sarawak, Malaysian Borneo. Holocene 23(11), 1528-1546.

Kalis, A.J., Merkt, J., Wunderlich, J., 2003. Environmental changes during the Holocene climatic optimum in central Europe - human impact and natural causes. Quaternary Science Reviews 22, 3379.

Killick, D. k., \& Miller, D., 2014. Smelting of magnetite and magnetite-ilmenite iron ores in the northern Lowveld, South Africa, ca. 1000 CE to ca. 1880 CE. Journal of Archaeological Science, 43239-255.

Kirk, Ryan W., Bolstad, P.V., Manson, S.M., 2012, Spatio-temporal trend analysis of long-term development patterns (1900-2030) in a Southern Appalachian County, Landscape and Urban Planning 104, 47-58. 
Knighton, A.D., 1998. Fluvial Forms and Processes: A New Perspective, and edition. Arnold, London.

Knox, J.C., 1987. Historical valley floor sedimentation in the upper Mississippi Valley. Annals of the Association of American Geographers 77, 224-244.

Knox, J.C., 2001. Agricultural influence on landscape sensitivity in the Upper Mississippi River Valley. Catena 42, 193-224.

Knox, J.C., 2006. Floodplain sedimentation in the Upper Mississippi Valley: Natural versus human accelerated. Geomorphology 79, 286-310.

Konert, M., Vandengerghe, J. 1997. Comparison of laser grain size analysis with pipette and sieve analysis: a solution for the underestimation of the clay fraction. Sedimentology 44, 523-535.

Lecce, S.A., 1997. Spatial patterns of historical overbank sedimentation and floodplain evolution, Blue River, Wisconsin. Geomorphology 18, 265-277.

Lecce, S.A., Pavlowsky, R.T., and Schlomer, G.S. 2008. Mercury contamination of active channel sediment and floodplain deposits from historic gold mining at Gold Hill, North Carolina, USA. Environmental Geology 55,113-121.

Lecce, S.A., Pavlowsky, R.T., Bassett, G.S., and Martin, D.J., 2011. Metal contamination from gold mining in the CID district, North Carolina. Physical Geography 32(5): 469-495.

Leigh, D.S., 1994. Mercury contamination and floodplain sedimentation from former gold-mines in north Georgia. Water resources bulletin 30, 739-748.

Leigh, D.S., 1997. Mercury-tainted overbank sediment from past gold mining in north Georgia, USA. Environmental Geology 30, 244-251.

Leigh, D.S., 2007. Human influence on Floodplain Sedimentation in the Upper Little Tennessee River Valley, Southern Blue Ridge Mountains, USA. Paper presented at the Annual Meeting of the Association of American Geographers, April 2007, San Francisco, CA.

Leigh, D.S., 2010. Morphology and channel evolution of small streams in the southern Blue Ridge Mountains of western North Caronlina. Southeastern Geographer 50(4): 397-421.

Leigh, D.S., 2016. Multi-millennial Record of Erosion and Fires in the Southern Blue Ridge Mountains, USA. In (K. Greenberg \& B. Collins, Eds.) pp. 167-202, "Natural Disturbances and Historic Range of Variation: Type, Frequency, Severity, and Post-disturbance Structure in Central Hardwood Forests, USA". New York: Springer.

Leigh, D.S., Webb, P.A., 2006. Holocene erosion, sedimentation, and stratigraphy at Raven Fork, Southern Blue Ridge Mountains, USA. Geomorphology 78, 161-177.

Leigh, D.S., Gragson, T.L., Coughlan, M.R., 2015. Colluvial legacies of millennial landscape change on individual hillsides, place-based investigation in the western Pyrenees Mountains. Quaternary International, in press. doi:10.1016/j.quaint.2015.08.031

Lewin, J., Macklin, M.G., 2005. Interpreting alluvial archives: sedimentological factors in the British Holocene fluvial record. Quaternary Science Review 24, 1873-1889. 
Liu, S., Rehren, T., Chen, J., Xu, C., Venunan, P., Larreina-Garcia, D., \& Martinón-Torres, M. (2015). Bullion production in imperial China and its significance for sulphide ore smelting world-wide. Journal of Archaeological Science, 55151-165. doi:10.1016/j.jas.2014.12.023

Macklin, M.G., Lewin, J., 2003. River sediments, great floods and centennial-scale Holocene climate change. Journal of Quaternary Science 18, 101-105.

Messick, D.P., Joseph, J.W., Adams, N.P., 2001. Tilling the Earth, Georgia's Historic Agricultural Heritage-a context: New South. http://georgiashpo.org/sites/uploads/hpd/pdf/tilling_the_earth.pdf. Last accessed on 09/01/2015.

Miller, J.R., Miller, S.O., 2007. Conaminated Rivers: A Geomorphological-Geochemical Approach to Site Assessment and Remediation.Netherlands: Springer: Dordrecht, Netherlands.

Miller, S.O., Ritter, D.F., Kochel, R.C., Miller, J.R., 1993. Fluvial responses to land-use changes and climatic variations within the Drury Creek watershed, southern Illinois. Geomorphology 6, 309-329.

Murray, A.S., Wintle, A.G., 2000. Luminescence dating of quartz using an improved single-aliquot regenerative-dose protocol. Radiation Measurements 27, $171-184$.

Munoz, S. E., Mladenoff, D. J., Schroeder, S., \& Williams, J. W., 2014. Defining the spatial patterns of historical land use associated with the indigenous societies of eastern North America. Journal of Biogeography, 41, 2195-2210.

Nichols, G., 1999. Sedimentology and stratigraphy. Blackwell Science Ltd, Oxford, UK. pp. 355.

Nriagu, J.O., 1994. Mercury pollution from the past mining of gold and silver in the Americas. Science of the Total Environment 149, 167-181.

Pardee, J.T., Park, C.F., 1948. Gold Deposits of the Southern Piedmont. US Geological Survey Professional Paper 213, pp.156.

Pavlowsky, R.T., Lecce, S.A., Bassett, G., Martin, D.J., 2010. Legacy Hg-Cu Contamination of Active Stream Sediments in the Gold Hill Mining District, North Carolina. Southeastern Geographer 50 (4), 503-522.

Price, K., Leigh, D.S., 2006. Morphological and sedimentological responses of streams to human impact in the southern Blue Ridge Mountains, USA. Geomorphology 78, 142-160.

R Development Core Team, 2008. R: A language and environment for statistical computing. R Foundation for Statistical Computing, Vienna, Austria. ISBN 3-900051-07-0, URL http://www.Rproject.org.

Reimer, P.J., Bard, E., Bayliss, A., Beck, J.W., Blackwell, P.G., Ramsey, C.B., Buck, C.E., Hai. C., Edwards, R.L., Friedrich, M., Grootes, P.M., Guilderson, T.P., Haflidason, H., Hajdas, I., Hatté, C., Heaton, T.J., Hoffmann, D.L., Hogg, A.G., Hughen, K.A., Kaiser, K.F., 2013. INTCAL13 and MARINE13 radiocarbon age calibration curves 0-50,000 years cal BP. Radiocarbon 55, 1869-1887.

Ritchie, J.C., McHenry, J.R., 1990. Application of radioactive fallout cesium-137 for measuring soil erosion and sediment. Journal of Environmental Quality 19, 215-233. 
Robinson, G.R. Jr., 1992. Bedrock geology and mineral resources of the Knoxville $1^{0}$ x $2^{0}$ quadrangle Tennessee, North Carolina, and South Carolina. US Geol Surv Bull 1979, US Geological Survey, Denver.

Santisteban, J.I., Mediavilla, R., Lopez-Pamo, E., Dabrio, C.J., Zapata, M.B.R., Garcia, M.J.G., et al., 2004. Loss on ignition: A qualitative or quantitative method for organic matter and carbonate mineral content in sediments. Journal of Paleolimnology 32, 287-299.

Soil Survey Division Staff, 1993. Soil Survey Manual. USDA Handbook No. 14. U.S. Government Printing Office, Washington, D.C.

Srivastava, P., Brook, G.A., Marais, E., 2005. Depositional environment and luminescence chronology of the Hoarusib River Clay Castles sediments, northern Namib Desert, Namibia. Catena 59, 187-204.

Stinchcomb, G.E., Messner, T.C., Driese, S.G., Nordt, L.C., Stewart, R.M., 2011. Pre-colonial (AD 1100-1600) sedimentation related to prehistoric maize agriculture and climate change in eastern North America. Geology 39, 363-366

Sutherland, A.S., Meyer, J.L., and Gardiner, E.P., 2002. Effects of land cover on sediment regime and fish assemblage structure in four southern Appalachian streams. Freshwater Biology 47, 1791-1805.

Swanton, J.R., 1946. The Indians of the Southeastern United States. Bureau of American Ethnology Bulletin 137.

Trimble, S.W., 1974. Man-induced soil erosion on the Southern Piedmont, 1700-1970. Soil Conservation Society of America, pp 180.

Van Doren, M., 1928. The travels of William Bartram. New York: Dover Publications.

Walling, D.E., He, Q., 1997. Use of fallout ${ }^{137} \mathrm{Cs}$ in investigations of overbank sediment deposition on river floodplains. Catena 29, 263-282.

Wang, L., Leigh, D.S., 2012. Late-Holocene paleofloods in the Upper Little Tennessee River valley, southern Blue Ridge Mountains, USA. The Holocene. 22, 1061-1066. DOI: 10.1177/095968361

Wang, L., 2010. Anthropic signatures and paleofloods in alluvium of the upper Little Tennessee River valley, southern Blue Ridge Mountains, USA. Master's Thesis. The University of Georgia, Athens.

Wolman, M.G., Leopold, L.B., 1957, River Flood Plains: Some Observations on their Formation, U.S. Geological Survey Professional Paper 282-C, pp. 30.

Wolf, D., A. Seim and D. Faust, 2014. Fluvial system response to external forcing and human impact; late Pleistocene and Holocene fluvial dynamics of the lower Guadalete River in western Andalucia (Spain). Boreas 43(2), 422-449.

$\mathrm{Xu}, \mathrm{J} ., 2003$. Sedimentation rates in the lower Yellow River over the past 2300 years as influenced by human activities and climate change. Hydrological Processes 17(16), 3359-3371.

Yarnell, S.L., 1998. The Southern Appalachians: A History of the Landscape. General Technical Report SRS-18, U.S. Department of Agriculture Forest Service Southern Research Station, Asheville, N.C. 


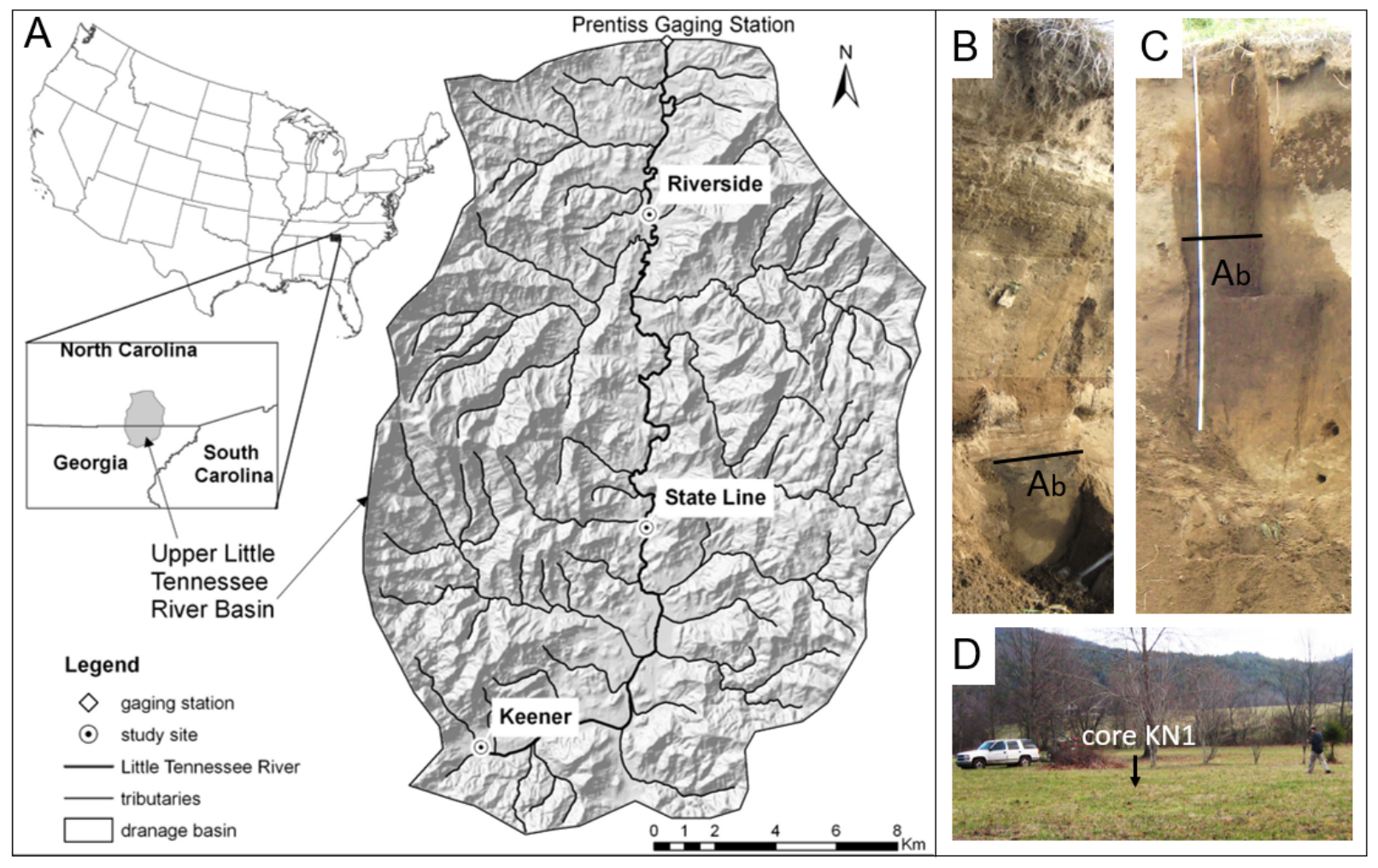

Figure 1. A. Location of the Upper Little Tennessee River Valley and the three sites in this study (Wang and Leigh, 2012). B. Vertical profile of the State Line site; C. Vertical profile of the Riverside site; D. Landscape of the Keener site and the location of core KN1. 
(A)

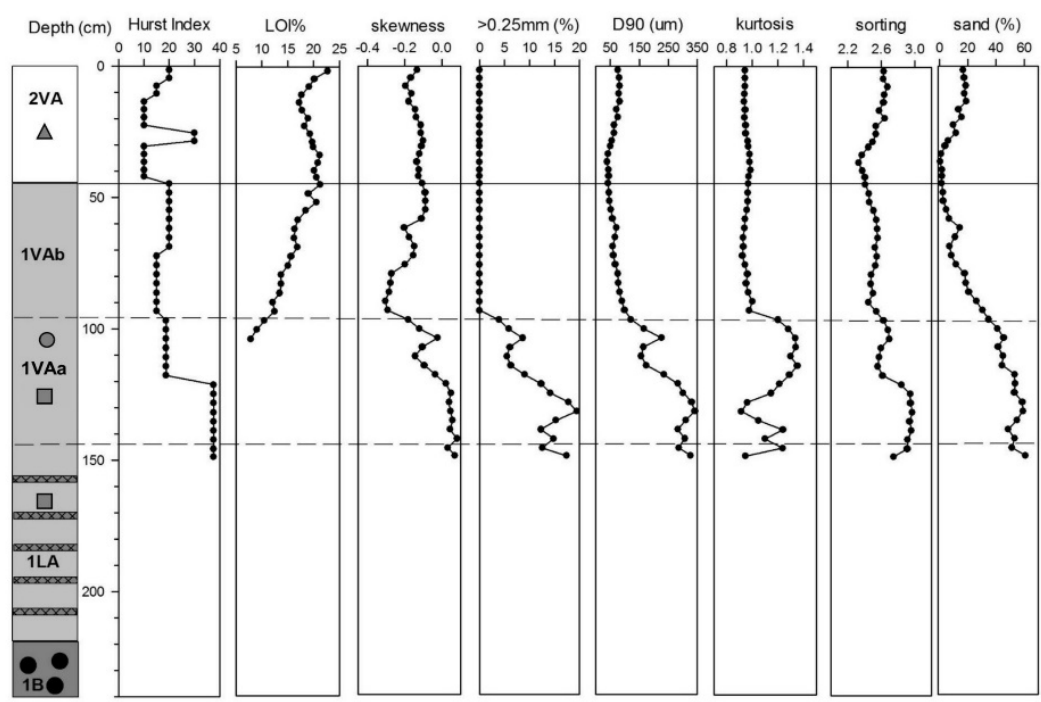

(B)

Depth (cm) Hurst Index LOl\% skewness $\quad>0.25 \mathrm{~mm}(\%) \quad$ D90 (um) $\quad$ kurtosis $\quad$ sorting sand(\%)

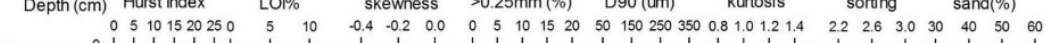

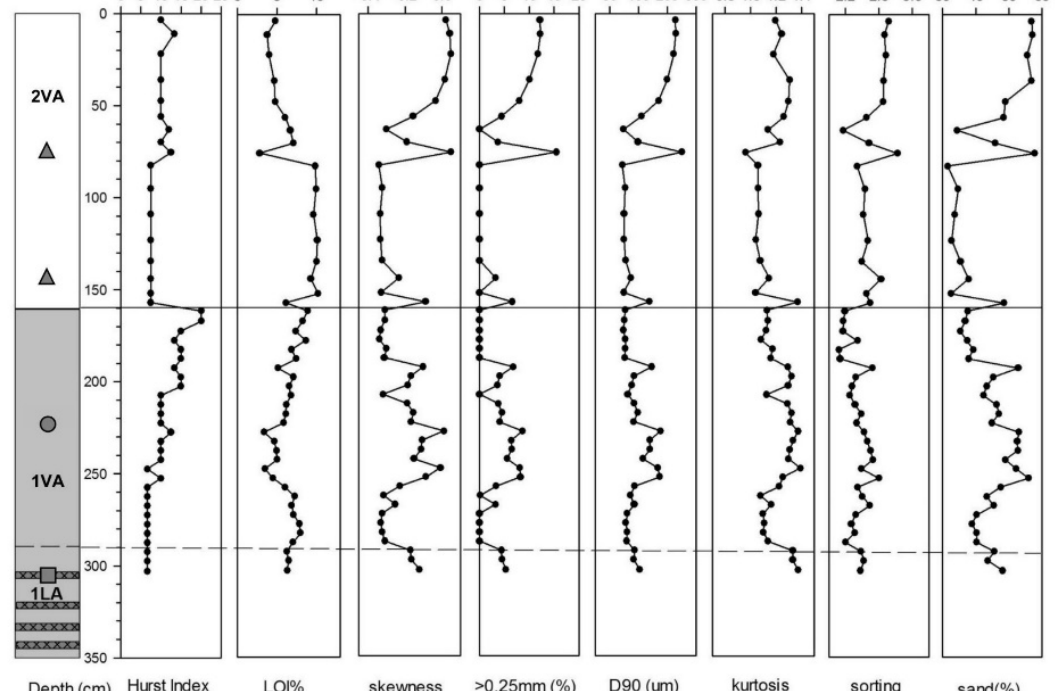

(C)

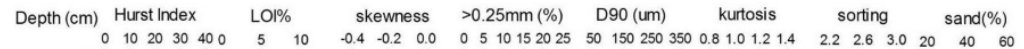

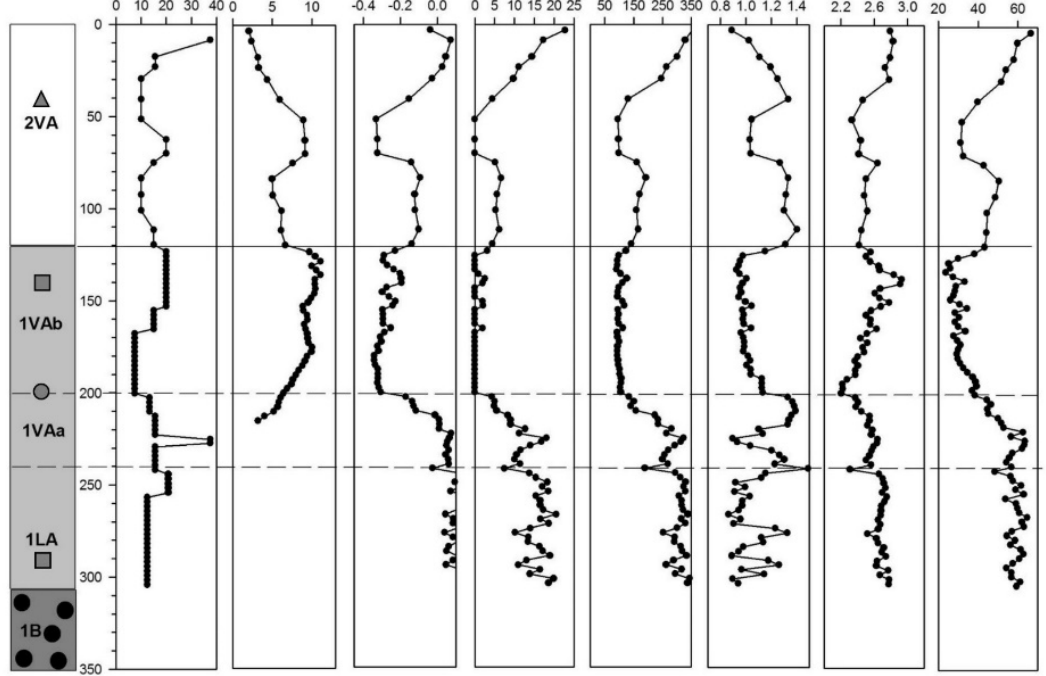

Legend:

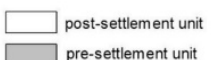

$\bullet$ bedload

VA vertical accretion unit

$\begin{array}{ll}\text { B: bedload unit } & \text { O OSL age } \\ & \square \text { radiocarbon age }\end{array}$ 
Figure 2. Stratigraphic units and particle size characteristics of the cores from the three sites. (A) the Keener site; (B) the State Line site; (C) the Riverside site

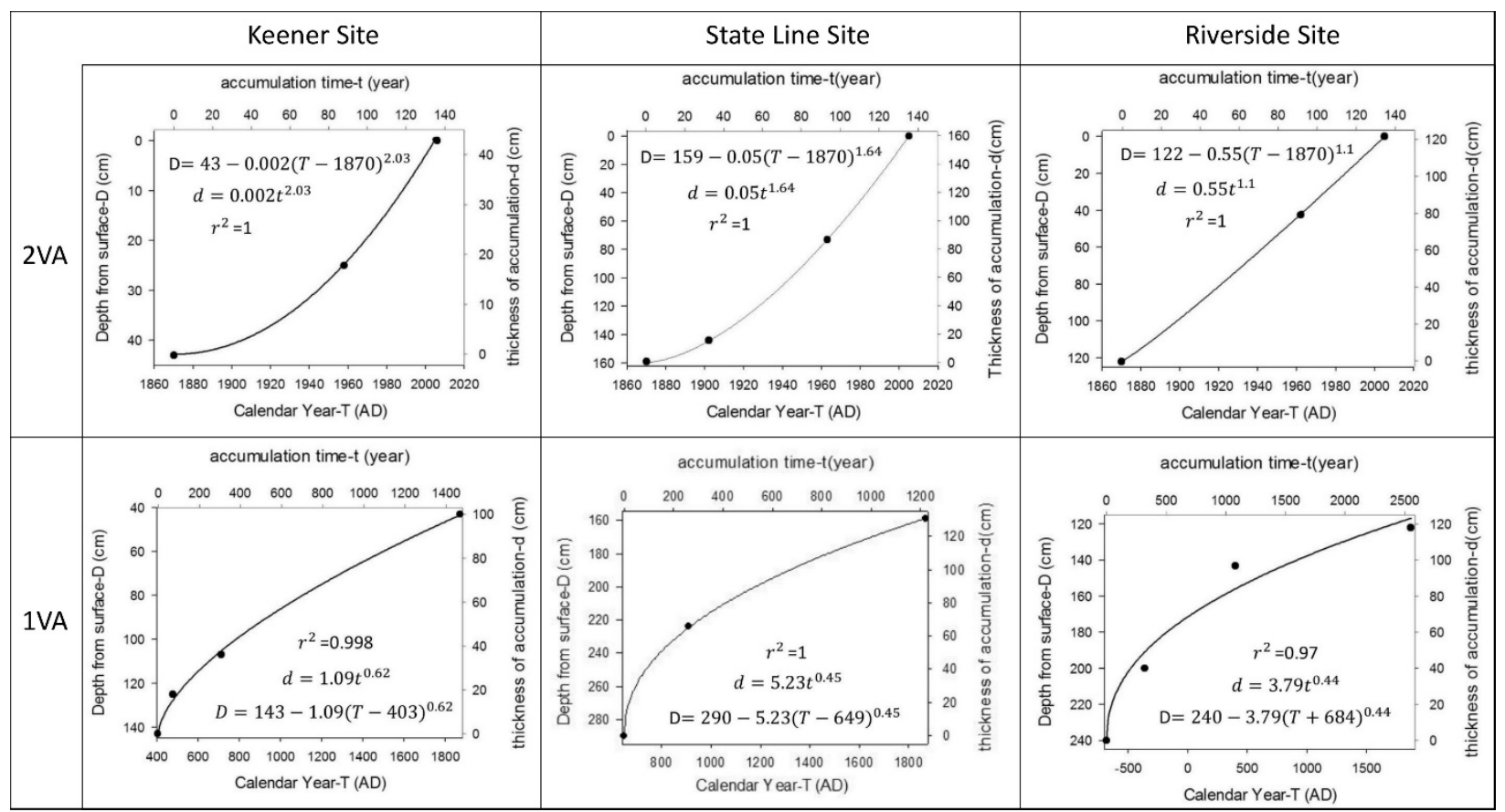

Figure 3. Age-depth models for vertical accretions during post-settlement (unit 2VA) and presettlement (unit 1VA) at the three study sites. $\mathrm{D}(\mathrm{cm})$ refers to the depth from the surface in the core, $T(A D)$ is the age in calendar years, $d(\mathrm{~cm})$ refers to the thickness of accumulation in the 1VA or 2VA units, $\mathrm{t}(\mathrm{yr})$ is the time of accumulation since the beginning of the 1VA or 2VA. 
(A)
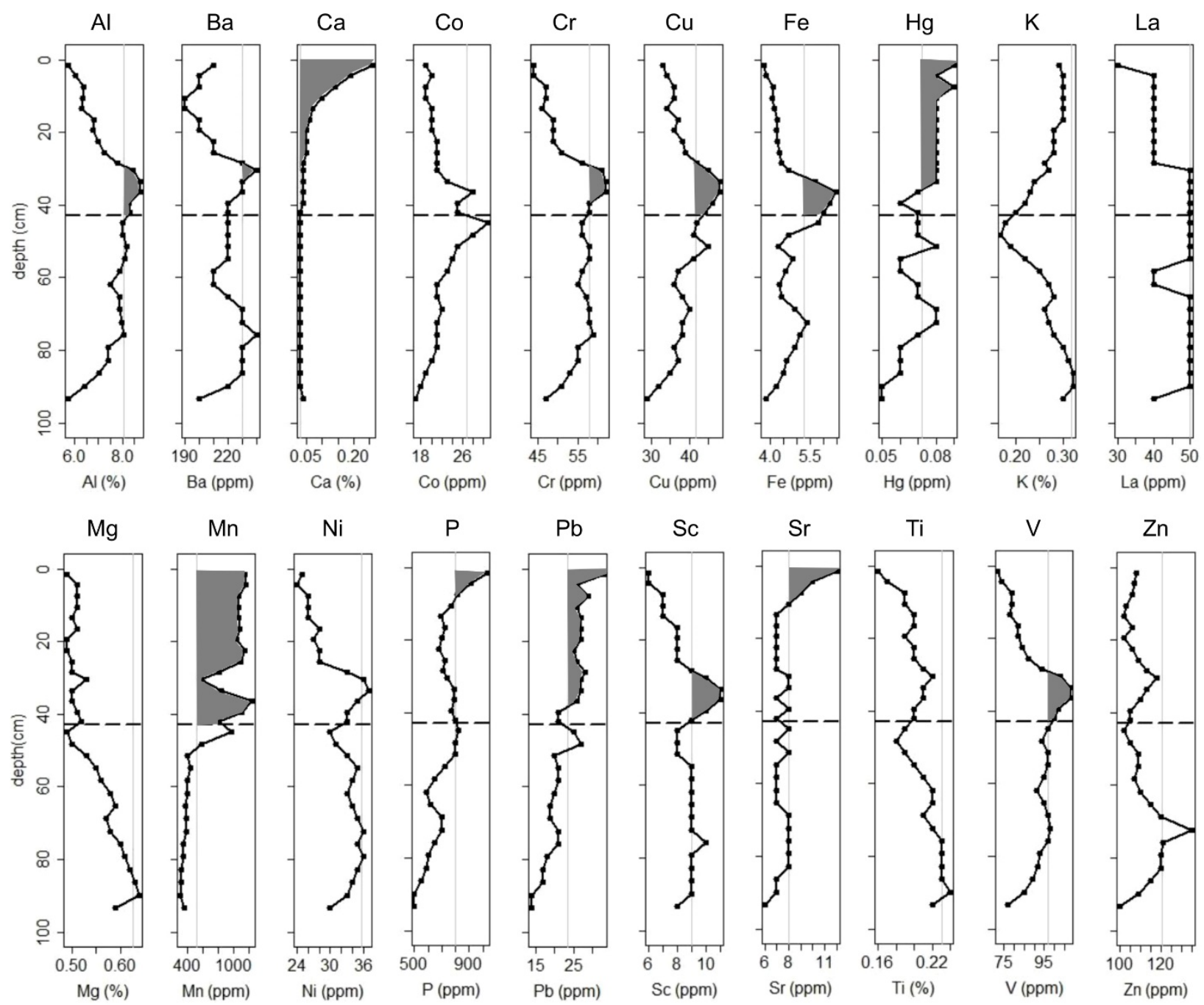
(B)
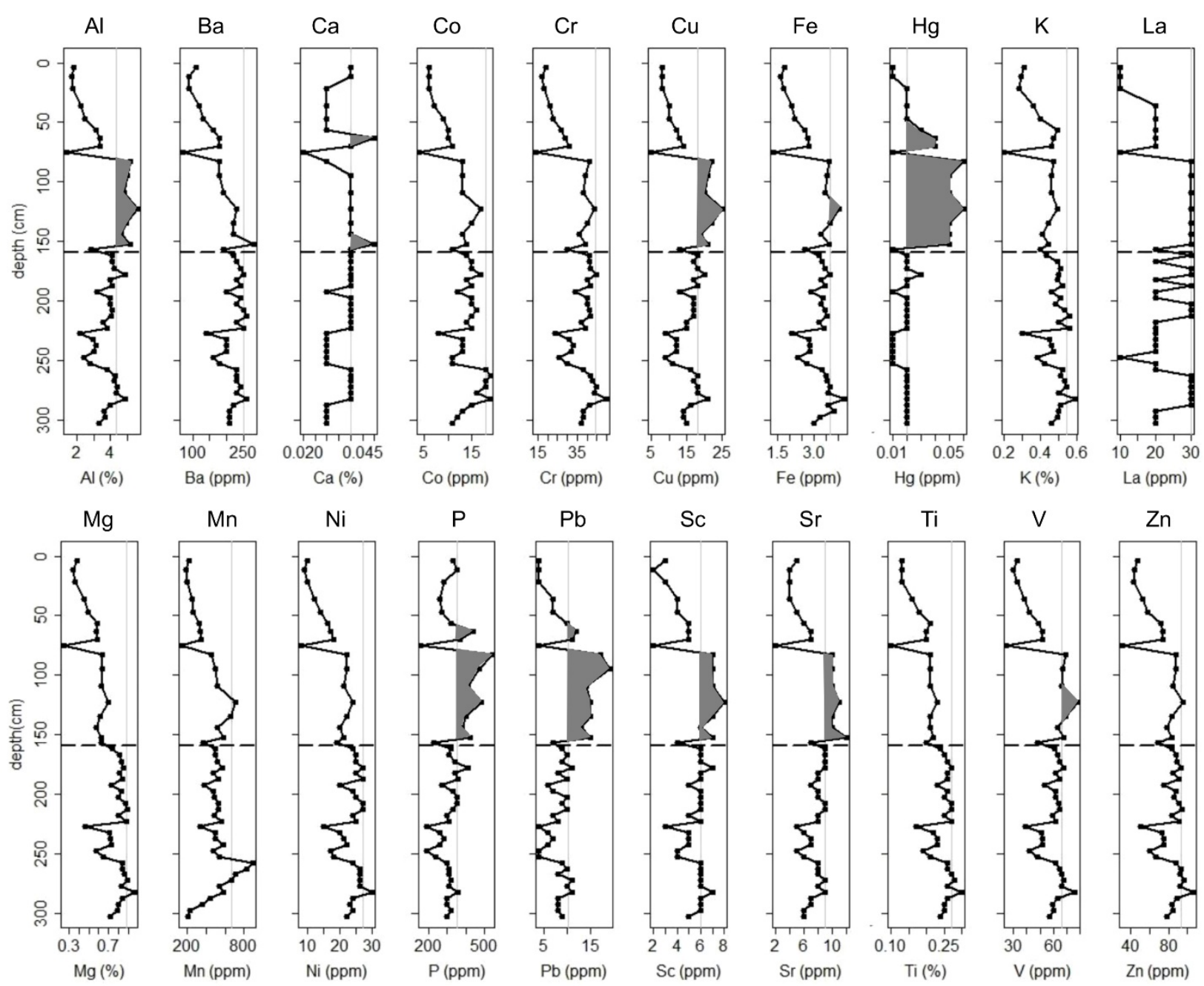
(C)
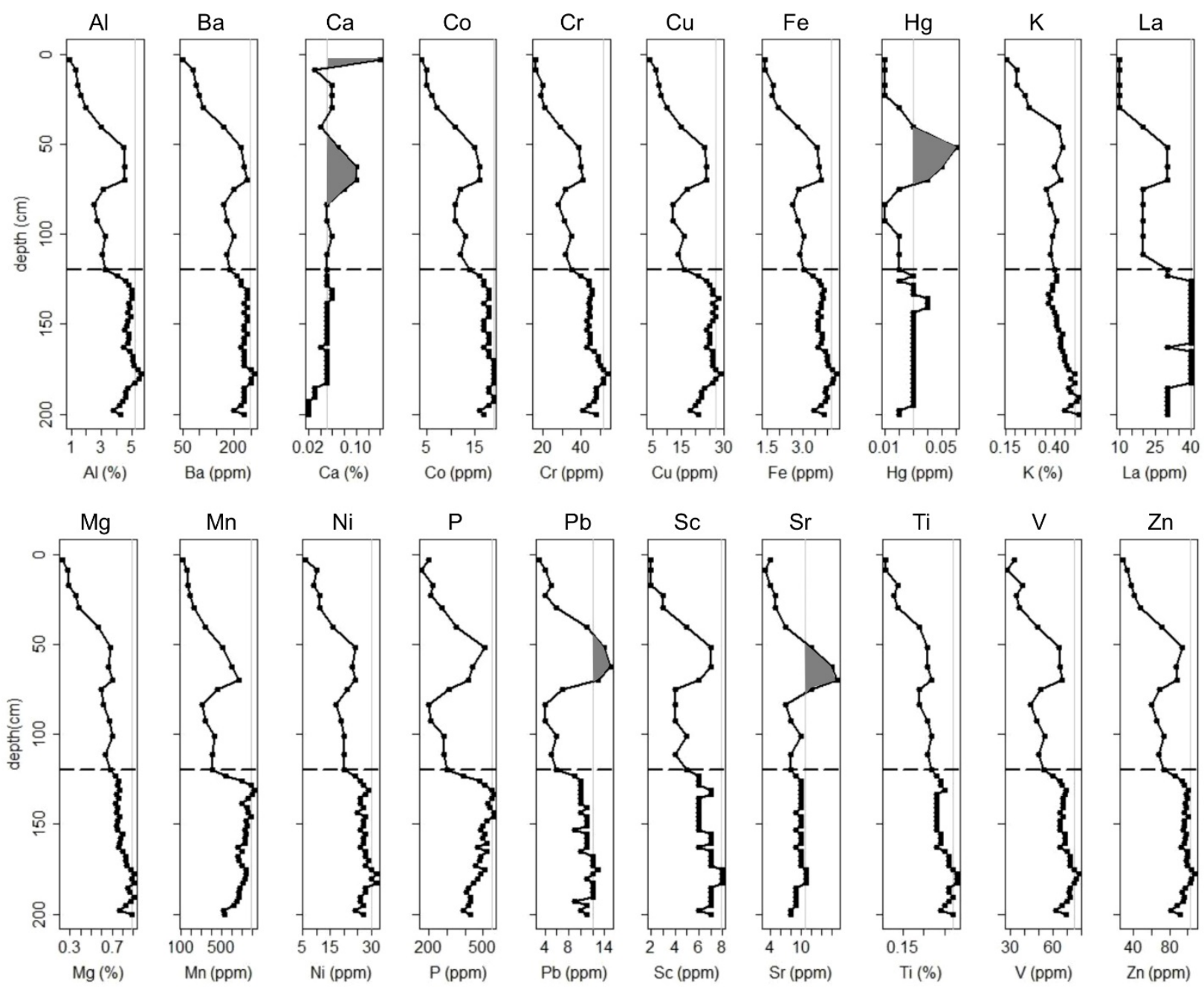

Figure 4. Original elemental concentrations at the three sites. (A) Keener site; (B) State Line site; (C) Riverside site. On each figure, dashed horizontal line represents the 2VA/1VA boundary, the light gray vertical line represents the $90^{\text {th }}$ percentile of data in unit $1 \mathrm{VA}$, and the dark grayshaded area shows where data in $2 \mathrm{VA}$ exceed $90^{\text {th }}$ percentile of background values derived from unit 1VA. 
(a)
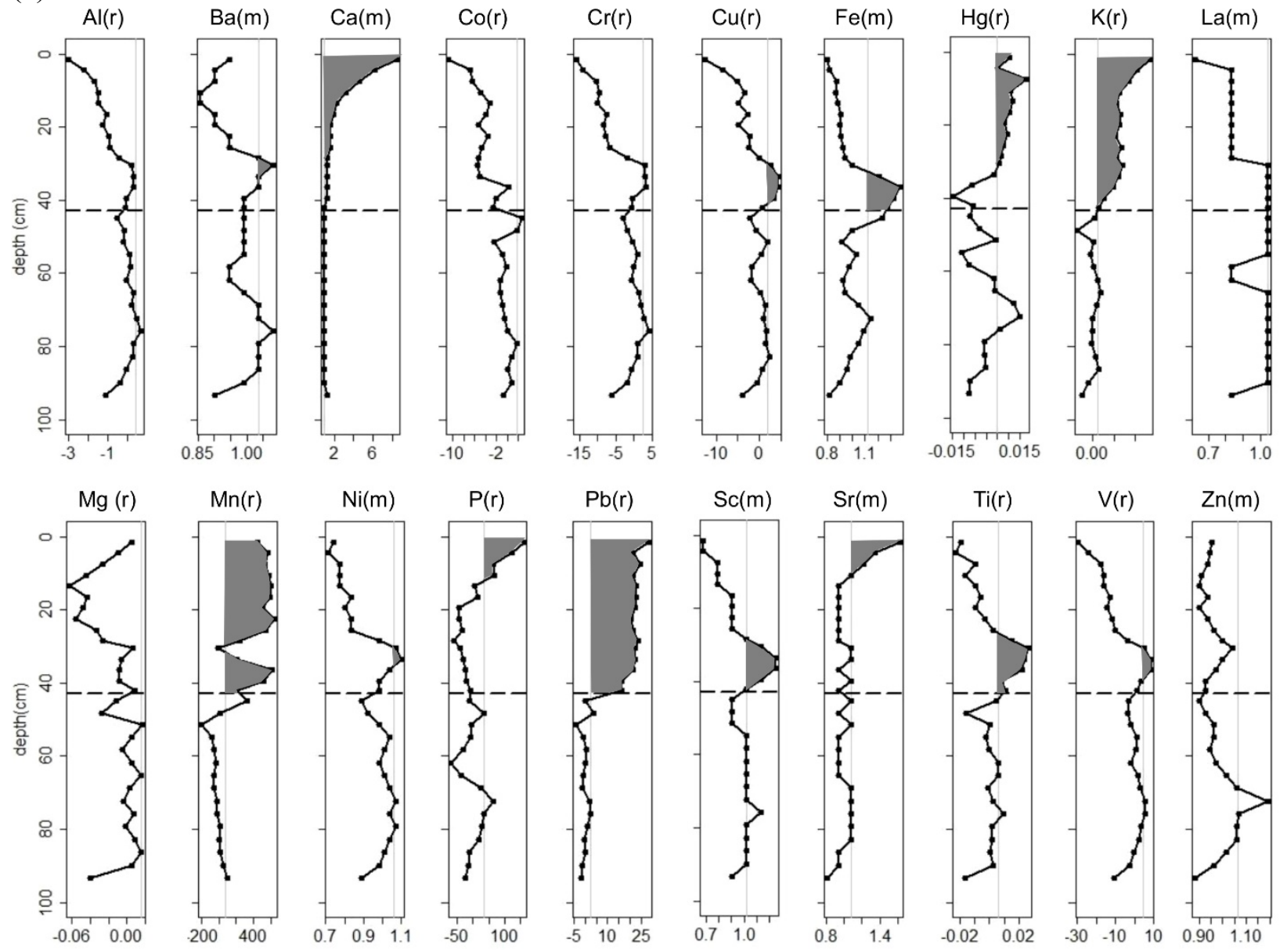
(b)
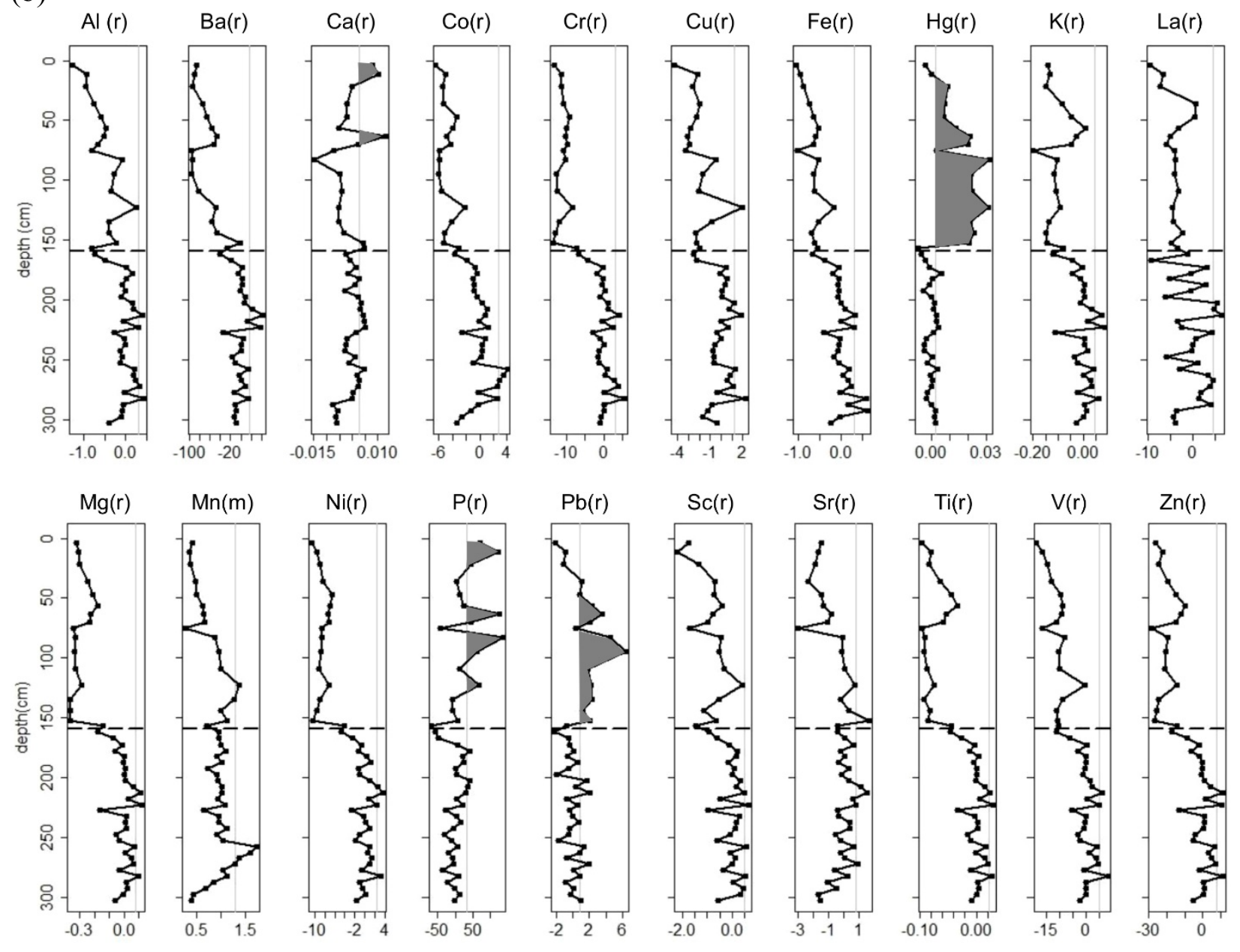
(c)
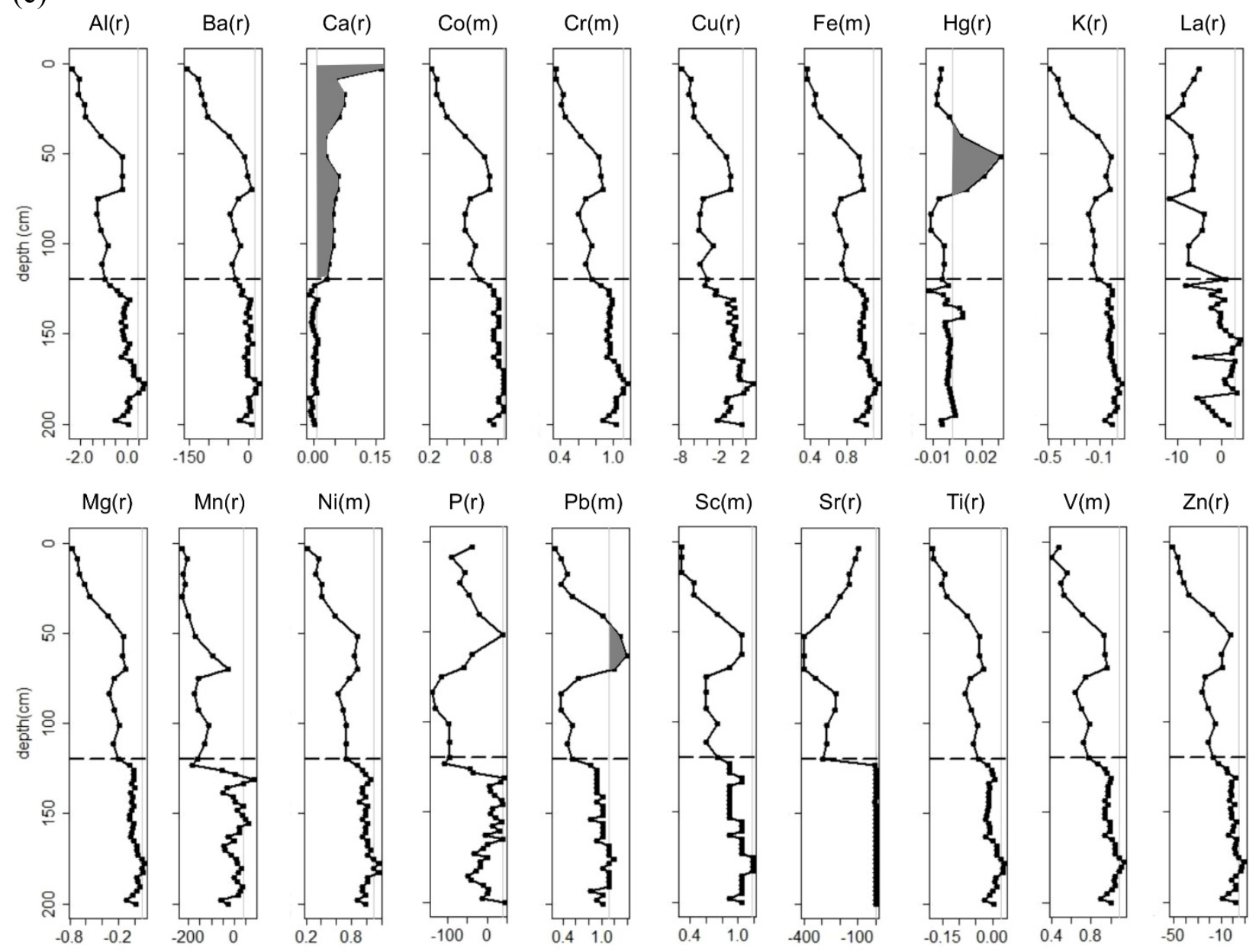

Figure 5. Residuals of chemical elements with depth at three sites. (a) Keener site; (b) State Line site; (c) Riverside site. The element is noted with (r) if residuals were derived from the linear regression on LOI, or with $(\mathrm{m})$ if residuals were differences from the mean concentrations of unit 1VA. On each figure, the dashed horizontal line represents the 2VA/1VA boundary, the light gray vertical line represents the $90^{\text {th }}$ percentile of data in unit $1 \mathrm{VA}$, and gray-shaded area indicates where data in $2 \mathrm{VA}$ exceed the $90^{\text {th }}$ percentile line of background values in unit $1 \mathrm{VA}$. 


\begin{tabular}{|c|c|c|c|c|c|c|c|c|c|c|}
\hline Site & Lab \# & $\begin{array}{c}\text { sample } \\
\text { depth } \\
(\mathrm{cm})\end{array}$ & $\begin{array}{l}\text { Unit \& } \\
\text { Facies }\end{array}$ & $\begin{array}{l}\text { Dating } \\
\text { Method }\end{array}$ & Material Dated & $\begin{array}{c}{ }^{14} \mathrm{C} \\
\text { years } \\
\text { BP }\end{array}$ & $\begin{array}{c}\text { Calibrated } \\
{ }^{14} \mathrm{C} \text { age } \\
\text { (cal. yr } \\
\text { BP) }\end{array}$ & $\begin{array}{c}\text { Non- }{ }^{14} \mathrm{C} \\
\text { Age } \\
\text { Estimate } \\
\text { cal. yr }\end{array}$ & \pm 1 SD & $\begin{array}{c}\text { Age } \\
\text { estimate } \\
(y r \\
\text { before } \\
\text { AD } \\
\text { 2009) }\end{array}$ \\
\hline Keener & n.a. & 0 & $2 \mathrm{VA}$ & GS & surface 2009 & n.a. & n.a. & AD 2009 & 1 & 0 \\
\hline Keener & n.a. & 13 & $2 \mathrm{VA}$ & Cs137 & flood sediment & n.a. & n.a. & AD 1958 & 10 & 51 \\
\hline Keener & n.a. & 43 & $1 / 2 \mathrm{VA}$ & CORR & top of $\mathrm{Ab}$ horizon & n.a. & n.a. & AD 1870 & 10 & 139 \\
\hline Keener & UGA-09OSL-672 & 107 & $1 \mathrm{VA}$ & OSL & sandy loam & n.a. & n.a. & $1300 *$ & 50 & 1300 \\
\hline Keener & UGA-14484 & 125 & $1 \mathrm{LA}$ & $\mathrm{C} 14$ & charcoal & 1620 & 1474 & n.a. & 40 & 1533 \\
\hline Keener & UGA-14485 & 143 & $1 \mathrm{LA}$ & $\mathrm{C} 14$ & acorn (uncarb.) & 1630 & 1546 & n.a. & 40 & 1605 \\
\hline State Line & n.a. & 0 & $2 \mathrm{VA}$ & CORR & surface 2009 & n.a. & n.a. & AD 2009 & 1 & 0 \\
\hline State Line & n.a. & 73 & $2 \mathrm{VA}$ & Cs 137 & flood sediment & n.a. & n.a. & AD 1964 & 10 & 45 \\
\hline State Line & n.a. & 144 & $2 \mathrm{VA}$ & CORR & flood sediment & n.a. & n.a. & AD 1902 & 10 & 107 \\
\hline State Line & n.a. & 159 & $1 / 2 \mathrm{VA}$ & CORR & top of $\mathrm{Ab}$ horizon & n.a. & n.a. & AD 1870 & 10 & 139 \\
\hline State Line & UGA-09OSL-670 & 225 & $1 \mathrm{VA}$ & OSL & $\begin{array}{c}\text { sandy loam } \\
\text { sediment }\end{array}$ & n.a. & n.a. & $1100 *$ & 50 & 1100 \\
\hline State Line & UGA-14480 & 290 & $1 \mathrm{LA}$ & $\mathrm{C} 14$ & leaf stem & 1380 & 1301 & n.a. & 40 & 1360 \\
\hline Riverside & n.a. & 0 & $2 \mathrm{VA}$ & GS & surface 2009 & n.a. & n.a. & AD 2009 & 1 & 0 \\
\hline Riverside & n.a. & 42.5 & $2 \mathrm{VA}$ & Cs137 & flood sediment & n.a. & n.a. & AD 1964 & 10 & 45 \\
\hline Riverside & n.a. & 122 & $1 / 2 \mathrm{VA}$ & CORR & top of $\mathrm{Ab}$ horizon & n.a. & n.a. & AD 1870 & 10 & 139 \\
\hline Riverside & UGAMS-10393 & 143.3 & $1 \mathrm{VA}$ & $\mathrm{C} 14$ & $<125$ um sediment & 1650 & 1552 & n.a. & 25 & 1611 \\
\hline Riverside & UGA-09OSL-669 & 200 & $1 \mathrm{VA}$ & OSL & $\begin{array}{c}\text { sandy loam } \\
\text { sediment }\end{array}$ & n.a. & n.a. & $2400 *$ & 150 & 2371 \\
\hline Riverside & UGA-9054 & 240 & $1 \mathrm{LA}$ & $\mathrm{C} 14$ & leaf & 2530 & 2634 & n.a. & 23 & 2693 \\
\hline
\end{tabular}


Table 2. Vertical sedimentation rates derived from depth-age model and average sedimentation rate for different periods. $R=$ deposition rate (in $\mathrm{cm} / \mathrm{yr}$ ); $t=$ deposition time (in year).

\begin{tabular}{ccccccc}
\hline & \multicolumn{3}{c}{ Sedimentation rate model } & \multicolumn{3}{c}{ Average sedimentation rate (mm/yr) } \\
\cline { 2 - 7 } Site & Post-settlement & Pre-settlement & Before & After & $1870-$ & $1964-$ \\
Keener & $R=0.004 t^{1.03}$ & $R=0.676 t^{-0.38}$ & 0.68 & 3.18 & 2.05 & 5.32 \\
State Line & $R=0.082 t^{0.64}$ & $R=2.35 t^{-0.55}$ & 1.07 & 11.78 & 9.25 & 17.38 \\
Riverside & $R=0.605 t^{0.1}$ & $R=1.67 t^{-0.56}$ & 0.46 & 9.04 & 8.70 & 9.77 \\
\hline
\end{tabular}

Table 3. Results of t-test or U-test on particle size parameters between unit 1VA and 2VA.

\begin{tabular}{|c|c|c|c|c|c|c|c|c|c|}
\hline & \multicolumn{3}{|c|}{ Keener } & \multicolumn{3}{|c|}{ State Line } & \multicolumn{3}{|c|}{ Riverside } \\
\hline & \multicolumn{3}{|c|}{ mean or median } & \multicolumn{3}{|c|}{ mean or median } & \multicolumn{3}{|c|}{ mean or median } \\
\hline & $2 \mathrm{VA}$ & $1 \mathrm{VAb}$ & $\mathrm{p}$-value & $2 \mathrm{VA}$ & $1 \mathrm{VA}$ & $\mathrm{p}$-value & $2 \mathrm{VA}$ & $1 \mathrm{VAb}$ & $\mathrm{p}$-value \\
\hline $\begin{array}{c}\text { mean } \\
(\mu \mathrm{m})\end{array}$ & 21.12 & 23.41 & 0.30 & 52.44 & 50.71 & 0.72 & 55.67 & 36.34 & $<0.001$ \\
\hline D90 $(\mu \mathrm{m})$ & 62.98 & 65.96 & 0.62 & 148.69 & 130.20 & 0.68 & 165.18 & 94.48 & $<0.001$ \\
\hline$>0.25 \%$ & 0.00 & 0.00 & 1.00 & 3.68 & 3.28 & 0.33 & 5.62 & 0.00 & $<0.001$ \\
\hline sand $\%$ & 10.92 & 14.09 & 0.50 & 45.90 & 44.10 & 0.76 & 44.50 & 30.00 & $<0.001$ \\
\hline sorting & 2.54 & 2.51 & 0.41 & 2.52 & 2.34 & $<0.001$ & 2.57 & 2.55 & 0.62 \\
\hline skewness & -0.13 & -0.18 & 0.23 & -0.19 & -0.24 & 0.54 & -0.12 & -0.29 & $<0.001$ \\
\hline kurtosis & 0.96 & 0.96 & 0.89 & 1.14 & 1.20 & 0.08 & 1.25 & 0.99 & $<0.001$ \\
\hline
\end{tabular}


Table 4. R-squared and p-values of linear regressions of original chemical concentrations on LOI using data in unit $1 \mathrm{VAb}$. Data are shown in boldface when the linear regression is not significant, in which case the residuals were simply calculated by subtracting the original concentrations by the mean of concentrations in 1VAb.

\begin{tabular}{|c|c|c|c|c|c|c|c|c|c|c|c|}
\hline & & Al & $\mathbf{B a}$ & $\mathrm{Ca}$ & Co & $\mathrm{Cr}$ & $\mathrm{Cu}$ & $\mathrm{Fe}$ & $\mathbf{H g}$ & $\mathbf{K}$ & $\mathbf{L a}$ \\
\hline \multirow[b]{2}{*}{ Keener } & $r^{2}$ & 0.58 & 0.01 & 0.13 & 0.86 & 0.37 & 0.8 & 0.2 & 0.39 & 0.92 & 0.03 \\
\hline & $\begin{array}{c}\mathrm{p}- \\
\text { value }\end{array}$ & $<0.01$ & 0.78 & 0.18 & $<0.01$ & 0.015 & $<0.01$ & 0.09 & 0.012 & $<0.01$ & 0.55 \\
\hline \multirow{2}{*}{$\begin{array}{l}\text { State } \\
\text { Line }\end{array}$} & $r^{2}$ & 0.85 & 0.6 & 0.49 & 0.47 & 0.82 & 0.86 & 0.64 & 0.7 & 0.37 & 0.48 \\
\hline & $\begin{array}{c}\mathrm{p}- \\
\text { value }\end{array}$ & $<0.01$ & $<0.01$ & $<0.01$ & $<0.01$ & $<0.01$ & $<0.01$ & $<0.01$ & $<0.01$ & $<0.01$ & $<0.01$ \\
\hline \multirow{2}{*}{ Riverside } & $r^{2}$ & 0.35 & 0.13 & 0.77 & 0.004 & 0.0006 & 0.64 & 0.0001 & 0.28 & 0.53 & 0.55 \\
\hline & $\begin{array}{c}\mathrm{p}- \\
\text { value }\end{array}$ & $<0.01$ & 0.04 & $<0.01$ & 0.74 & 0.9 & $<0.01$ & 0.94 & 0.002 & $<0.01$ & $<0.01$ \\
\hline & & $\mathrm{Mg}$ & Mn & $\mathbf{N i}$ & $\mathbf{P}$ & $\mathbf{P b}$ & Sc & $\mathrm{Sr}$ & $\mathbf{T i}$ & $\mathbf{V}$ & Zn \\
\hline \multirow{2}{*}{ Keener } & $r^{2}$ & 0.87 & 0.53 & 0.08 & 0.89 & 0.7 & 0.21 & 0.09 & 0.84 & 0.45 & 0.08 \\
\hline & $\begin{array}{c}\mathrm{p}- \\
\text { value }\end{array}$ & $<0.01$ & $<0.01$ & 0.3 & $<0.01$ & $<0.01$ & 0.09 & 0.28 & $<0.01$ & $<0.01$ & 0.3 \\
\hline \multirow{2}{*}{$\begin{array}{l}\text { State } \\
\text { Line }\end{array}$} & $\mathrm{r}^{2}$ & 0.54 & 0.04 & 0.7 & 0.71 & 0.72 & 0.74 & 0.65 & 0.6 & 0.76 & 0.68 \\
\hline & $\begin{array}{c}\mathrm{p}- \\
\text { value }\end{array}$ & $<0.01$ & 0.29 & $<0.01$ & $<0.01$ & $<0.01$ & $<0.01$ & $<0.01$ & $<0.01$ & $<0.01$ & $<0.01$ \\
\hline \multirow{2}{*}{ Riverside } & $\mathrm{r}^{2}$ & 0.24 & 0.58 & 0.03 & 0.57 & 0.006 & 0.05 & 0.43 & 0.15 & 0.0006 & 0.29 \\
\hline & $\begin{array}{c}\mathrm{p}- \\
\text { value }\end{array}$ & 0.004 & $<0.01$ & 0.38 & $<0.01$ & 0.67 & 0.22 & $<0.01$ & 0.03 & 0.89 & 0.001 \\
\hline
\end{tabular}

Table 5. p-values of t-test or U-test on chemical residuals between unit 1VAb and 2VA. Data are shown in boldface when residuals in unit 2VA are significantly greater than in unit 1VAb.

\begin{tabular}{ccccccccccc}
\hline & $\mathrm{Al}$ & $\mathrm{Ba}$ & $\mathrm{Ca}$ & $\mathrm{Co}$ & $\mathrm{Cr}$ & $\mathrm{Cu}$ & $\mathrm{Fe}$ & $\mathrm{Hg}$ & $\mathrm{K}$ & $\mathrm{La}$ \\
\hline Keener & 0.003 & 0.048 & $\mathbf{0 . 0 1}$ & $<0.001$ & 0.005 & 0.13 & 0.98 & $\mathbf{0 . 0 4}$ & $<\mathbf{0 . 0 0 1}$ & 0.008 \\
State & $<0.001$ & $<0.001$ & 0.69 & $<0.001$ & $<0.001$ & $<0.001$ & $<0.001$ & $<\mathbf{0 . 0 0 1}$ & $<0.001$ & $<0.001$ \\
Line & & & & & & & & & & \\
Riverside & $<0.001$ & $<0.001$ & $<\mathbf{0 . 0 0 1}$ & $<0.001$ & $<0.001$ & $<0.001$ & $<0.001$ & 0.89 & 0.0002 & $<0.001$ \\
\hline & $\mathrm{Mg}$ & $\mathrm{Mn}$ & $\mathrm{Ni}$ & $\mathrm{P}$ & $\mathrm{Pb}$ & $\mathrm{Sc}$ & $\mathrm{Sr}$ & $\mathrm{Ti}$ & $\mathrm{V}$ & $\mathrm{Zn}$ \\
\hline Keener & 0.004 & $<\mathbf{0 . 0 0 1}$ & 0.004 & 0.65 & $<\mathbf{0 . 0 0 1}$ & 0.31 & 0.2 & 0.84 & $\mathbf{0 . 0 2}$ & 0.04 \\
State & $<0.001$ & 0.01 & $<0.001$ & $\mathbf{0 . 0 2}$ & $\mathbf{0 . 0 1}$ & $<0.001$ & 0.02 & $<0.001$ & $<0.001$ & $<0.001$ \\
Line & & & & & & & & & & \\
Riverside & $<0.001$ & $<0.001$ & $<0.001$ & $<0.001$ & 0.003 & $<0.001$ & $<0.001$ & $<0.001$ & $<0.001$ & $<0.001$ \\
\hline
\end{tabular}


Table 6. Standard coefficient and predictive accuracy of discriminant function analysis. Prediction uses leave-one-out cross-validation method.

\begin{tabular}{cccc}
\hline & Keener & State Line & Riverside \\
\hline $\mathrm{Hg}$ & -48.30 & 201.69 & 121.43 \\
$\mathrm{~Pb}$ & 0.52 & -0.11 & -0.31 \\
$\mathrm{Ca}$ & -16.70 & 51.39 & 32.17 \\
sand $\%$ & 0.08 & -0.14 & -0.05 \\
$\mathrm{LOI}$ & 0.25 & 0.03 & -0.39 \\
\hline predictive & $100 \%$ & $89 \%$ & $96 \%$ \\
accuracy & & & \\
\hline
\end{tabular}

